\title{
Understanding the role of metallocenium ion pairs aggregates on the rate of olefin insertion into the metal-carbon bond
}

\author{
Leonardo Sian, Alceo Macchioni, Cristiano Zuccaccia* \\ Dipartimento di Chimica, Biologia e Biotecnologie, Università di Perugia, Via Elce di Sotto 8, 06123 \\ Perugia, Italy. Dutch Polymer Institute (DPI), P.O. Box 902, 5600 AX Eindhoven, The Netherlands
}

Corresponding author e-mail: cristiano.zuccaccia@unipg.it

\section{SUPPORTING INFORMATION}

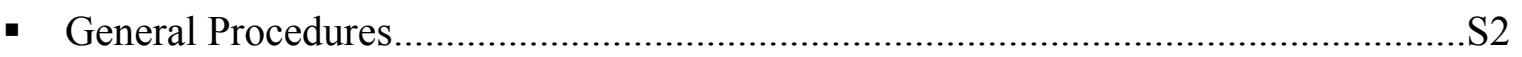

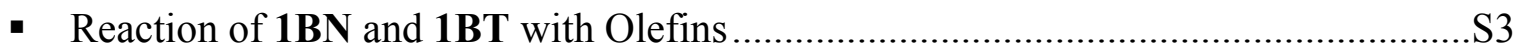

- Thermodynamic of Ion Pairs Self-Aggregation

- PGSE NMR Diffusion Experiments..............................................................S10

- Thermodynamic parameters of self-aggregation.............................................S16

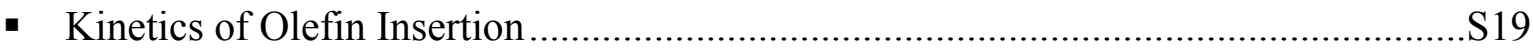

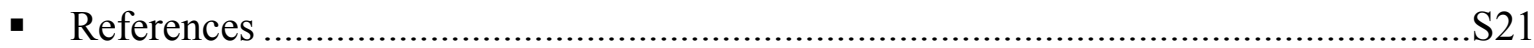




\section{General Procedures}

All manipulations of air-sensitive chemicals were performed with rigorous exclusion of oxygen and moisture in flamed Schlenk-type glassware interfaced to a high-vacuum line ( $10^{-5}$ Torr $)$ or in a nitrogen-filled MBraun glovebox $\left(<0.5 \mathrm{ppm}_{2}\right.$ and $\left.\mathrm{H}_{2} \mathrm{O}\right)$. Molecular sieves were activated for $24 \mathrm{~h}$ at ca. $200-230{ }^{\circ} \mathrm{C}$ under dynamic vacuum. All solvents were freeze-pump-thaw degassed on the high vacuum line, dried over the appropriate drying agent $\left(\mathrm{Na} / \mathrm{K}\right.$ alloy for benzene, pentane, benzene- $\mathrm{d}_{6}$, toluene- $\mathrm{d}_{8}$, methylcyclohexane- $\mathrm{d}_{14} ; \mathrm{CaH}_{2}$ for chlorobenzene- $\mathrm{d}_{5}$ ) and vacuum transferred into dry storage Schlenk flasks equipped with PTFE valves. 1hexene (4) and 2-methyl-1-heptene (5) were purchased from SIGMA-Aldrich, freeze-pump-thaw degassed on the high vacuum line, dried over $\mathrm{CaH}_{2}$, vacuum transferred to a dry storage Schlenk flask equipped with PTFE valve and stored at $-30{ }^{\circ} \mathrm{C}$ inside the glovebox. $\mathrm{CH}_{3} \mathrm{~N}\left(\mathrm{C}_{18} \mathrm{H}_{37}\right)_{2}$ was purchased from SIGMA-Aldrich and used as received. $\left[\mathrm{CPh}_{3}\right]\left[\mathrm{B}\left(\mathrm{C}_{6} \mathrm{~F}_{5}\right)_{4}\right]$ was obtained from Boulder Scientific Company and used as received. $\mathrm{B}\left(\mathrm{C}_{6} \mathrm{~F}_{5}\right)_{3}$ was obtained from Boulder Scientific Company and purified by sublimation (40-60 $\left.{ }^{\circ} \mathrm{C}, 10^{-5} \mathrm{Torr}\right) . \mathrm{Cp}_{2} \mathrm{ZrMe}_{2},{ }^{[1]}$ $\left[\mathrm{Cp}_{2} \mathrm{Zr}\left(\eta^{2}-\mathrm{CH}_{2} \mathrm{~N}\left(\mathrm{C}_{18} \mathrm{H}_{37}\right)_{2} \cdots \mathrm{MeB}\left(\mathrm{C}_{6} \mathrm{~F}_{5}\right)_{3}{ }^{-}\right](\mathbf{1 B N})^{[2]}\right.$ and $\left[\mathrm{Cp}_{2} \mathrm{Zr}\left(\eta^{2}-\mathrm{CH}_{2} \mathrm{~N}\left(\mathrm{C}_{18} \mathrm{H}_{37}\right)_{2} \cdots \mathrm{B}\left(\mathrm{C}_{6} \mathrm{~F}_{5}\right)_{4}^{-}\right]\right.$(1BT) ${ }^{[2]}$ were synthesized according to the literature. One- and two-dimensional NMR spectra were recorded on a Bruker Avance III 400 spectrometer equipped with a smartprobe and using standard pulse sequences. Referencing is relative to external TMS $\left({ }^{1} \mathrm{H}\right.$ and $\left.{ }^{13} \mathrm{C}\right)$ and $\mathrm{CCl}_{3} \mathrm{~F}\left({ }^{19} \mathrm{~F}\right)$. 


\section{Reaction of 1BN and 1BT with Olefins}

The reactivity of $\mathbf{1 B N}$ and $\mathbf{1 B T}$ with olefins is summarized in Scheme S1.
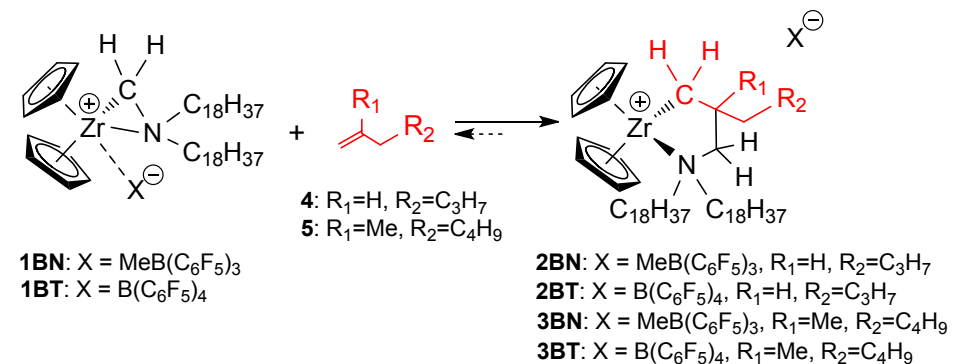

Scheme S1. Reaction of $1 B N$ and $1 B T$ with olefins.

Synthesis of $\mathrm{Cp}_{2} \mathrm{Zr}\left(\kappa^{2}\left(\mathrm{CH}_{2}-\mathrm{CH}\left(\mathrm{C}_{4} \mathrm{H}_{9}\right)-\mathrm{CH}_{2}-\mathrm{N}\left(\mathrm{C}_{18} \mathrm{H}_{37}\right)_{2}\right]^{+}\left[\mathrm{MeB}\left(\mathrm{C}_{6} \mathrm{~F}_{5}\right)_{3}\right]^{-}\right.$(2BN). A $20 \mathrm{mM}$ solution of $\mathbf{1 B N}$ in $0.6 \mathrm{~mL}$ of benzene- $\mathrm{d}_{6}(0.012 \mathrm{mmol})$ was loaded into a J. Young NMR tube and 1.3 equivalents of $4(0.016$ mmol, $0.002 \mathrm{~mL}$ ) were added. An immediate colour change from brown to orange was observed. After 15 minutes, the J. Young NMR tube was interfaced to the high-vacuum line and volatiles were removed under vacuum. The resulting oil was dissolved in $0.6 \mathrm{~mL}$ of benzene- $\mathrm{d}_{6}$ for NMR characterization. The ${ }^{1} \mathrm{H}$ NMR spectrum of $\mathbf{2 B N}$ with resonance assignment is showed in Figure S1. ${ }^{1} \mathrm{H}$ NMR (benzene- $\mathrm{d}_{6}, 298 \mathrm{~K}, 400.13$ $\mathrm{MHz}, \mathrm{J}$ in $\mathrm{Hz}) \delta=5.73\left(\mathrm{~s}, \mathrm{Cp}^{\mathrm{u}}\right), 5.71\left(\mathrm{~s}, \mathrm{Cp}^{\mathrm{d}}\right), 2.78\left(\mathrm{td}^{3} \mathrm{~J}=13.05,{ }^{2} \mathrm{~J}=4.86, \mathrm{H}^{\mathrm{d}} \mathrm{a}^{\mathrm{d}}\right), 2.53\left(\mathrm{t}^{3} \mathrm{~J}=13.08, \mathrm{H} 1 \mathrm{a}^{\mathrm{d}}\right), 2.34$

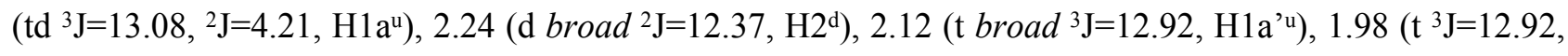
$\left.\mathrm{H} 2^{\mathrm{u}}\right), 1.67$ (m, H3 $\left.{ }^{\mathrm{d}}\right), 1.35$ (buried, m, H4 $\left.{ }^{\mathrm{u}}\right), 1.45-1.05$ (m, H3a-c $\left.\mathrm{c}^{\mathrm{u}}, \mathrm{H} 1 \mathrm{c}^{\mathrm{d}}, \mathrm{H} 1 \mathrm{c}^{\mathrm{u}}\right), 1.17$ (buried, m, H1 b $\left.{ }^{\mathrm{u}}\right), 1.13$ (buried, m, H4 ${ }^{\mathrm{d}}$ ), 1.05 (buried, m, H1b (b) $^{\mathrm{d}} .02$ ( $\left.\mathrm{t},{ }^{3} \mathrm{~J}=7.85, \mathrm{H} 3 \mathrm{a}-\mathrm{d}^{\mathrm{u}}, \mathrm{H} 1 \mathrm{~d}^{\mathrm{d}}, \mathrm{H} 1 \mathrm{~d}^{\mathrm{u}}\right), 0.93$ ( $\mathrm{t},{ }^{3} \mathrm{~J}=6.95, \mathrm{H} 3 \mathrm{~d}^{\mathrm{u}}, \mathrm{H} 1 \mathrm{~d}^{\mathrm{d}}$, $\left.\mathrm{H}^{\mathrm{u}} \mathrm{d}^{\mathrm{u}}\right), 0.58$ (broad, H1b'd), -0.22 (m, H1b'u). ${ }^{13} \mathrm{C}\left\{{ }^{1} \mathrm{H}\right\}$ NMR (benzene- $\left.\mathrm{d}_{6}, 298 \mathrm{~K}, 100.55 \mathrm{MHz}\right) \delta=115\left(\mathrm{Cp}^{\mathrm{u}}\right)$,

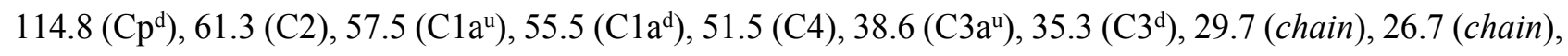
$24.7\left(\mathrm{C} 1 b^{\mathrm{u}}\right), 22.8$ (chain), $21.2\left(\mathrm{C}^{\mathrm{d}} \mathrm{b}^{\mathrm{d}}\right), 14.1\left(\mathrm{C} 3 \mathrm{~d}, \mathrm{C} 1 \mathrm{~d}^{\mathrm{d}}, \mathrm{C} 1 \mathrm{~d}^{\mathrm{u}}\right), 13.8\left(\mathrm{C} 3 \mathrm{~d}, \mathrm{C} 1 \mathrm{~d}^{\mathrm{d}}, \mathrm{C} 1 \mathrm{~d}^{\mathrm{u}}\right) .{ }^{19} \mathrm{~F}$ NMR (benzene$\mathrm{d}_{6}, 298 \mathrm{~K}, 376.65 \mathrm{MHz}, \mathrm{J}$ in Hz) $\delta=-131.8$ (d broad, o-F), -163.8 (t broad, $\left.p-\mathrm{F}\right),-166.4$ (m, m-F). 


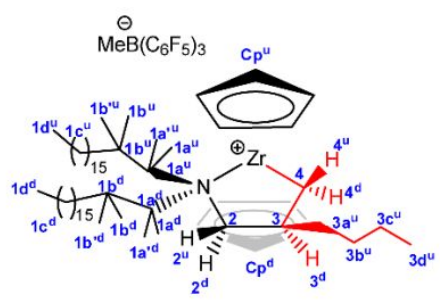

2BN
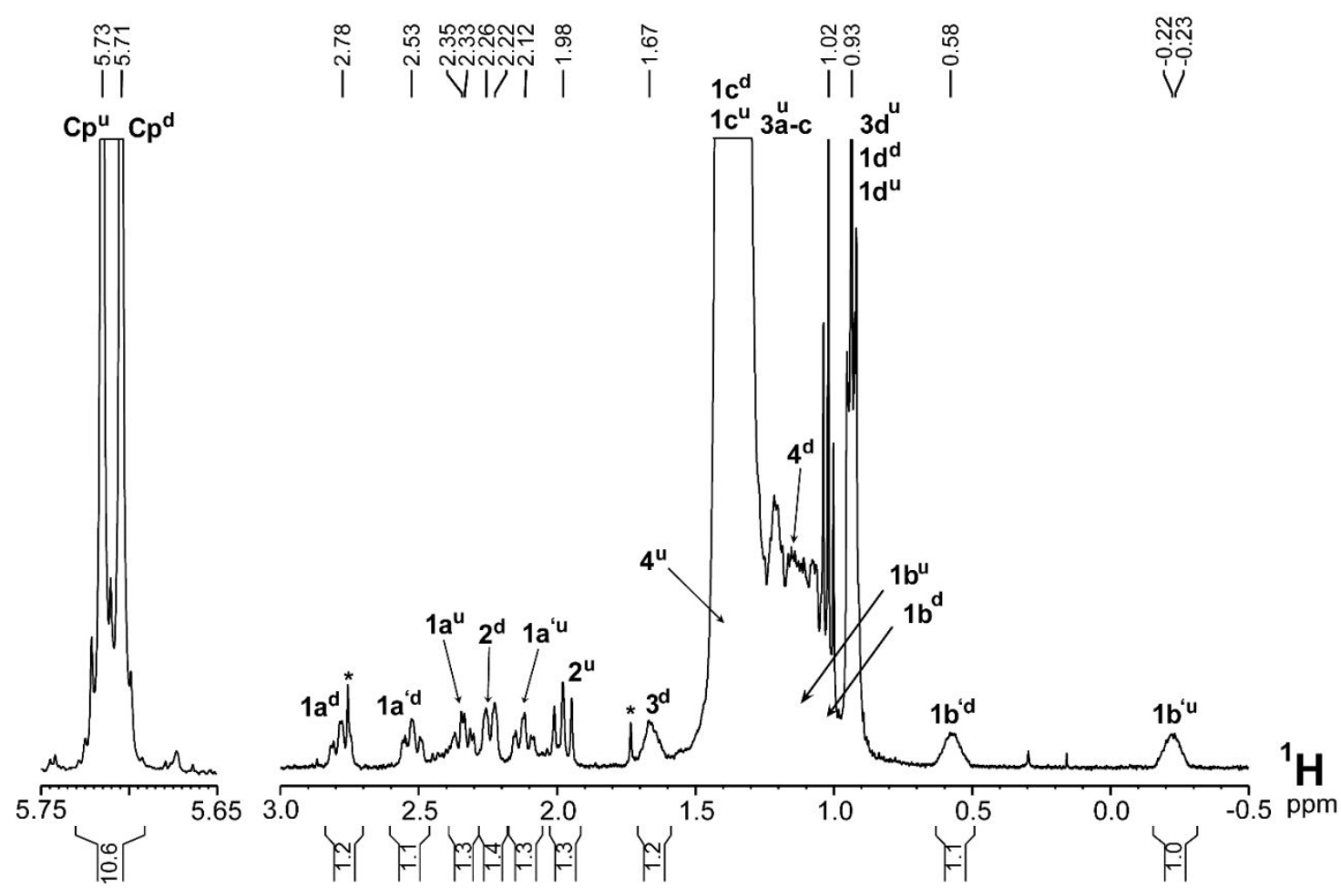

Figure S1. Sections of ${ }^{1} H$ NMR spectrum of $\mathbf{2 B N}$ in benzene-d ${ }_{6}$ at $298 K$. Asterisks denote impurities.

Synthesis of $\mathrm{Cp}_{2} \mathrm{Zr}\left(\kappa^{2}\left(\mathrm{CH}_{2}-\mathrm{CH}\left(\mathrm{C}_{4} \mathrm{H}_{9}\right)-\mathrm{CH}_{2}-\mathrm{N}\left(\mathrm{C}_{18} \mathrm{H}_{37}\right)_{2}\right]^{+}\left[\mathrm{B}\left(\mathrm{C}_{6} \mathrm{~F}_{5}\right)_{4}\right]^{-}\right.$(2BT). A $20 \mathrm{mM}$ solution of $1 \mathbf{B T}$ in 0.6 $\mathrm{mL}$ of benzene- $\mathrm{d}_{6}(0.012 \mathrm{mmol})$ was loaded into a J. Young NMR tube and 1.3 equivalents of $4(0.016 \mathrm{mmol}$, $0.002 \mathrm{~mL}$ ) were added. An immediate colour change from brown to orange was observed. After 10 minutes, the J. Young NMR tube was interfaced to the high-vacuum line and volatiles were removed under vacuum. The resulting oil was dissolved in $0.6 \mathrm{~mL}$ of benzene- $\mathrm{d}_{6}$ for NMR characterization. ${ }^{1} \mathrm{H}$ NMR spectrum of $\mathbf{2 B T}$ with resonance assignment is showed in Figure S2. ${ }^{1} \mathrm{H}$ NMR (benzene- $\mathrm{d}_{6}, 298 \mathrm{~K}, 400.13 \mathrm{MHz}, \mathrm{J}$ in $\mathrm{Hz}$ ) $\delta=$ $5.79\left(\mathrm{~s}, \mathrm{Cp}^{\mathrm{u}}\right), 5.76\left(\mathrm{~s}, \mathrm{Cp}^{\mathrm{d}}\right), 2.87\left(\mathrm{t}^{3} \mathrm{~J}=11.70, \mathrm{H}_{1} \mathrm{a}^{\mathrm{d}}\right), 2.54\left(\mathrm{t}^{3} \mathrm{~J}=11.13, \mathrm{H} 1 \mathrm{a}^{\mathrm{d}}\right), 2.39\left(\mathrm{td}^{3} \mathrm{~J}=12.69,{ }^{2} \mathrm{~J}=4.01, \mathrm{H}^{\mathrm{a}} \mathrm{a}^{\mathrm{u}}\right)$, $2.31\left(\mathrm{~d}^{2} \mathrm{~J}=13.35, \mathrm{H}^{\mathrm{d}}\right), 2.14\left(\mathrm{td}^{3} \mathrm{~J}=12.69, \mathrm{H}^{\mathrm{a}} \mathrm{a}^{\mathrm{u}}\right), 2.06\left(\mathrm{t}^{3} \mathrm{~J}=12.02, \mathrm{H} 2^{\mathrm{u}}\right), 1.72\left(\mathrm{~m}, \mathrm{H} 3^{\mathrm{d}}\right), 1.42$ (buried, $\left.\mathrm{m}, \mathrm{H} 4^{\mathrm{u}}\right)$,

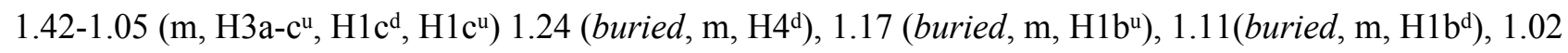
$\left(\mathrm{t},{ }^{3} \mathrm{~J}=7.85, \mathrm{H} 3 \mathrm{a}-\mathrm{d}^{\mathrm{u}}, \mathrm{H} 1 \mathrm{~d}^{\mathrm{d}}, \mathrm{H} 1 \mathrm{~d}^{\mathrm{u}}\right), 0.94$ (t, $\left.{ }^{3} \mathrm{~J}=6.95, \mathrm{H}^{3} \mathrm{~d}^{\mathrm{u}}, \mathrm{H}_{1} \mathrm{~d}^{\mathrm{d}}, \mathrm{H} 1 \mathrm{~d}^{\mathrm{u}}\right), 0.59$ (m, H1b'd $), 0.26$ (m, H1b'u). ${ }^{13} \mathrm{C}\left\{{ }^{1} \mathrm{H}\right\}$ NMR (benzene-d $\left.6,298 \mathrm{~K}, 100.55 \mathrm{MHz}\right) \delta=114.9\left(\mathrm{Cp}^{\mathrm{u}}\right), 114.7\left(\mathrm{Cp}^{\mathrm{d}}\right), 60.9(\mathrm{C} 2), 57.3\left({\left.\mathrm{C} 1 \mathrm{a}^{\mathrm{u}}\right), 55.5}\right.$ $\left(\mathrm{Cla}^{\mathrm{d}}\right), 51.4(\mathrm{C} 4), 38.5\left(\mathrm{C} 3 \mathrm{a}^{\mathrm{u}}\right), 35.4\left(\mathrm{C}^{\mathrm{d}}\right), 32.1$ (chain), 29.7 (chain), 26.7 (chain), $24.9\left(\mathrm{Clb}^{\mathrm{u}}\right), 22.7$ (chain), 
$21.0\left(\mathrm{Clb}^{\mathrm{d}}\right), 14.0\left(\mathrm{C}^{\mathrm{d}}, \mathrm{C} 1 \mathrm{~d}^{\mathrm{d}}, \mathrm{C} 1 \mathrm{~d}^{\mathrm{u}}\right), 13.8\left(\mathrm{C}^{\mathrm{d}}, \mathrm{C} 1 \mathrm{~d}^{\mathrm{d}}, \mathrm{C} 1 \mathrm{~d}^{\mathrm{u}}\right) .{ }^{19} \mathrm{~F}$ NMR (benzene- $\mathrm{d}_{6}, 298 \mathrm{~K}, 376.65 \mathrm{MHz}, \mathrm{J}$ in $\mathrm{Hz}) \delta=-131.7(\mathrm{~d}$ broad, $o-\mathrm{F}),-162.2\left(\mathrm{t},{ }^{3} \mathrm{~J}_{\mathrm{mF}-\mathrm{pF}}=20.8, p-\mathrm{F}\right),-166.1(\mathrm{~m}, m-\mathrm{F})$.

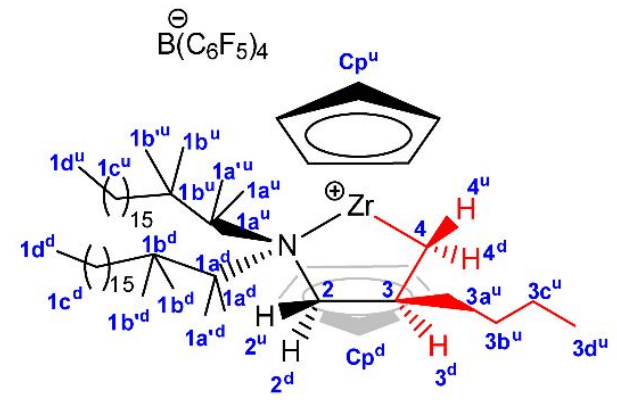

2BT

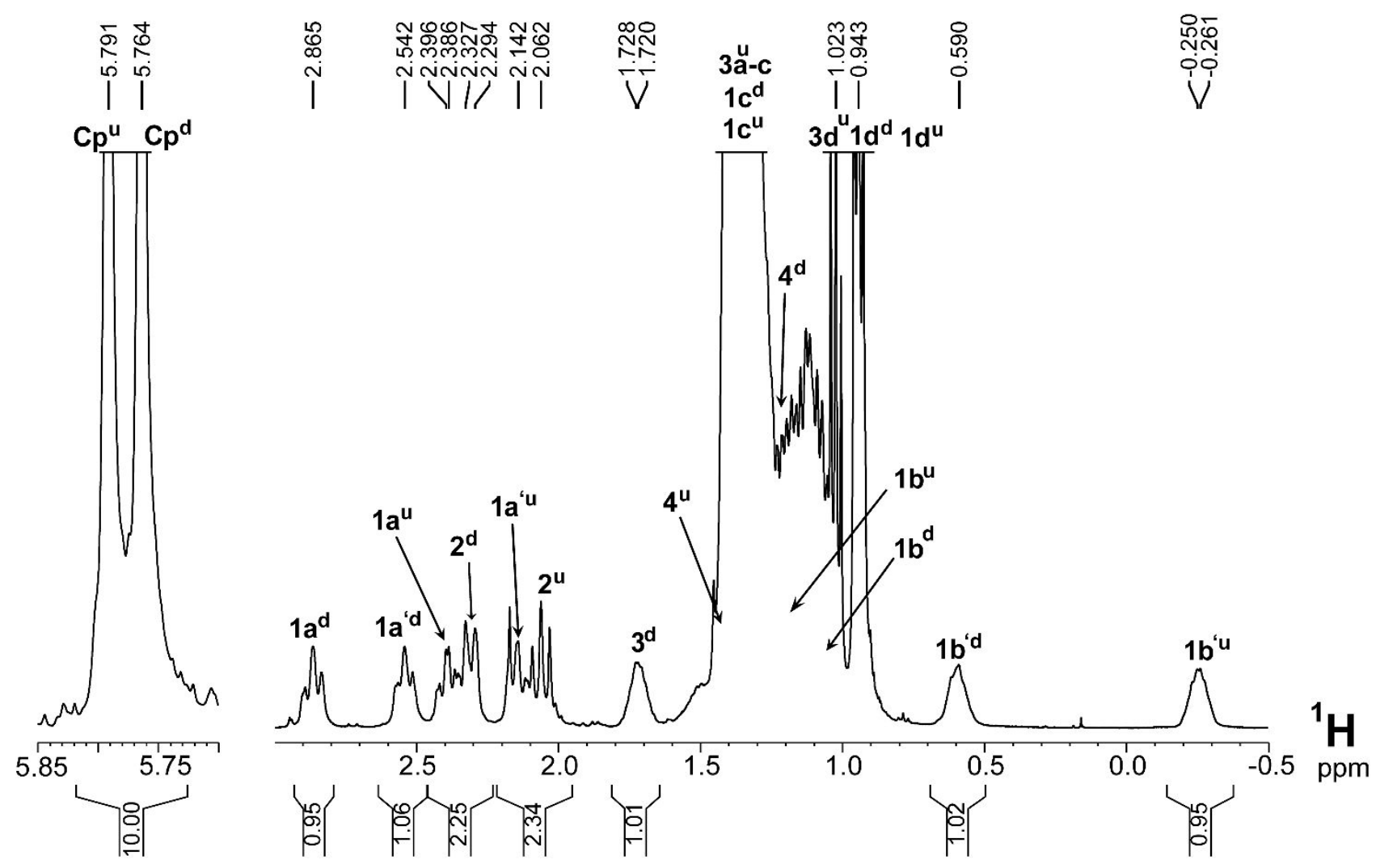

Figure S2. Sections of ${ }^{1} H$ NMR spectrum of $\mathbf{2 B T}$ in benzene- $d_{6}$ at $298 \mathrm{~K}$. 
Generation of $\mathrm{Cp}_{2} \mathrm{Zr}\left(\kappa^{2}\left(\mathrm{CH}_{2}-\mathrm{CMe}\left(\mathrm{C}_{5} \mathrm{H}_{11}\right)-\mathrm{CH}_{2}-\mathrm{N}\left(\mathrm{C}_{18} \mathrm{H}_{37}\right)_{2}\right]^{+}\left[\mathrm{MeB}\left(\mathrm{C}_{6} \mathrm{~F}_{5}\right)_{3}\right]^{-} \mathbf{( 3 B N}\right)$. A $5 \mathrm{mM}$ solution of $\mathbf{1 B N}$ in $0.6 \mathrm{~mL}$ of methylcyclohexane- $\mathrm{d}_{14}(0.003 \mathrm{mmol})$ was loaded into a J. Young NMR tube and 17 equivalents of $5(0.015 \mathrm{mmol}, 0.0024 \mathrm{~mL})$ were added. The reaction was very slow and only $2 \%$ of conversion of $\mathbf{1 B N}$ into 3BN was observed in 10 hours. Addition of 250 equivalents of 5 to the previous solution $(0.75 \mathrm{mmol}, 0.12$ $\mathrm{mL}$ ) resulted in about $40 \%$ conversion of $1 \mathbf{B N}$ to $3 \mathbf{B N}$ in a few minutes. The reaction was monitored for additional 14 hours but no further reactions were observed. The appearance of two singlets at $6.2 \mathrm{ppm}$ is consistent with the formation of $\mathbf{3 B N}$, as showed in the ${ }^{1} \mathrm{H}$ NMR spectrum in Figure $\mathrm{S} 3$.

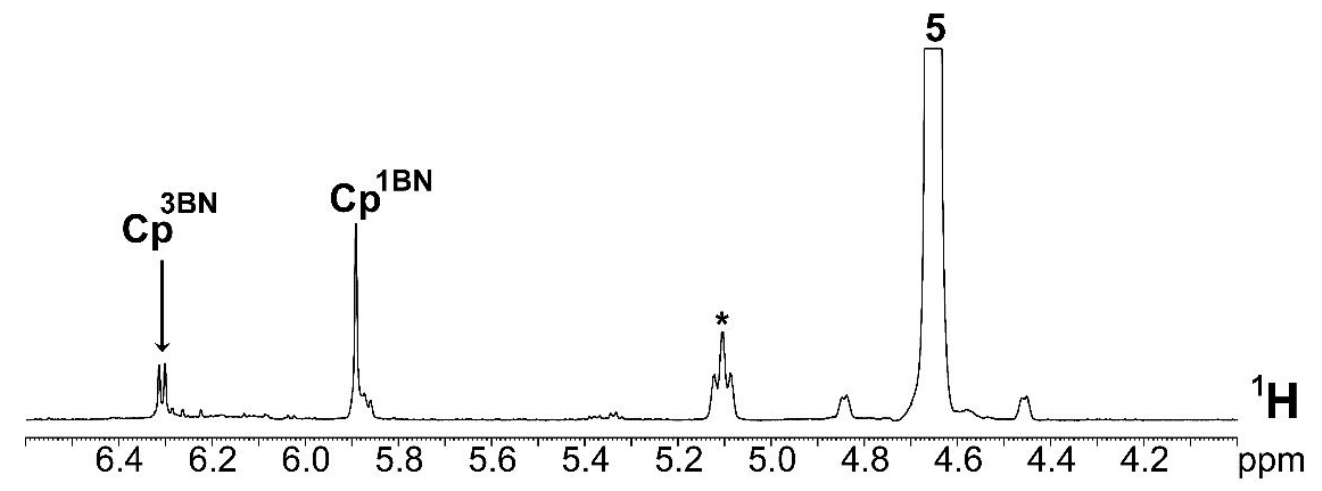

Figure S3. Section of ${ }^{1} H$ NMR spectrum of $3 \mathbf{B N}$ ion pair in benzene-d ${ }_{6}$ at $298 \mathrm{~K} 14$ hours after the addition of 250 equivalents of 5 . Asterisk denote impurity.

Synthesis of $\mathrm{Cp}_{2} \mathrm{Zr}\left(\kappa^{2}\left(\mathrm{CH}_{2}-\mathrm{CMe}\left(\mathrm{C}_{5} \mathrm{H}_{11}\right)-\mathrm{CH}_{2}-\mathrm{N}\left(\mathrm{C}_{18} \mathrm{H}_{37}\right)_{2}\right]^{+}\left[\mathrm{B}\left(\mathrm{C}_{6} \mathrm{~F}_{5}\right)_{4}\right]^{-}\right.$(3BT). A $20 \mathrm{mM}$ solution of $1 \mathbf{B T}$ in 0.6 $\mathrm{mL}$ of benzene- $\mathrm{d}_{6}(0.012 \mathrm{mmol})$ was loaded into a J. Young NMR tube and 18 equivalents of $5(0.216 \mathrm{mmol}$, $0.034 \mathrm{~mL}$ ) were added. An immediate colour change from brown to orange was observed. After 15 minutes, full conversion of $1 B T$ to $3 B$ T was observed. Since 3BT is in equilibrium with $1 B T$ and $\mathbf{5}$, excess 5 cannot be removed from solution and 3BT was directly characterized in solution by NMR spectroscopy. ${ }^{1} \mathrm{H}$ NMR spectrum of 3BT with complete resonance assignment is showed in Figure S4. ${ }^{1} \mathrm{H}$ NMR (benzene- $\mathrm{d}_{6}, 298 \mathrm{~K}$, $400.13 \mathrm{MHz}, \mathrm{J}$ in $\mathrm{Hz}) \delta=6.00\left(\mathrm{~s}, \mathrm{Cp}^{\mathrm{u}}\right), 5.98\left(\mathrm{~s}, \mathrm{Cp}^{\mathrm{d}}\right), 2.80$ (brt, H1a $\left.^{\mathrm{d}}\right), 2.78$ (t broad, H1 a $), 2.62(\mathrm{~d}$ broad, $\left.{ }^{2} \mathrm{~J}=14.17, \mathrm{H} 2{ }^{\mathrm{d}}\right), 2.54$ (t broad, H1a'd), 2.49 (d broad, $\left.{ }^{2} \mathrm{~J}=14.15, \mathrm{H} 2^{\mathrm{u}}\right), 2.45$ (t broad, H1a'u), 1.59 (buried, H5 ${ }^{\mathrm{d}}$ ),

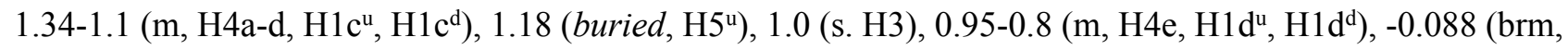
H1b'd $),-0.11$ (brm, H1b'u). ${ }^{13} \mathrm{C}\left\{{ }^{1} \mathrm{H}\right\}$ NMR (benzene-d $\left.{ }_{6}, 298 \mathrm{~K}, 100.55 \mathrm{MHz}\right) \delta=115.0\left(\mathrm{Cp}^{\mathrm{d}}\right), 114.8\left(\mathrm{Cp}^{\mathrm{u}}\right), 65.9$

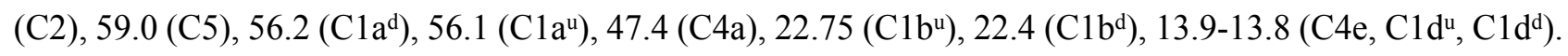
${ }^{19} \mathrm{~F}$ NMR (benzene-d $\mathrm{d}_{6}, 298 \mathrm{~K}, 376.65 \mathrm{MHz}, \mathrm{J}$ in $\left.\mathrm{Hz}\right) \delta=-131.7$ (d broad, $\left.o-\mathrm{F}\right),-163.0\left(\mathrm{t},{ }^{3} \mathrm{~J}_{\mathrm{mF}-\mathrm{pF}}=20.3, p-\mathrm{F}\right),-$ $166.1(\mathrm{~m}, m-\mathrm{F})$. 

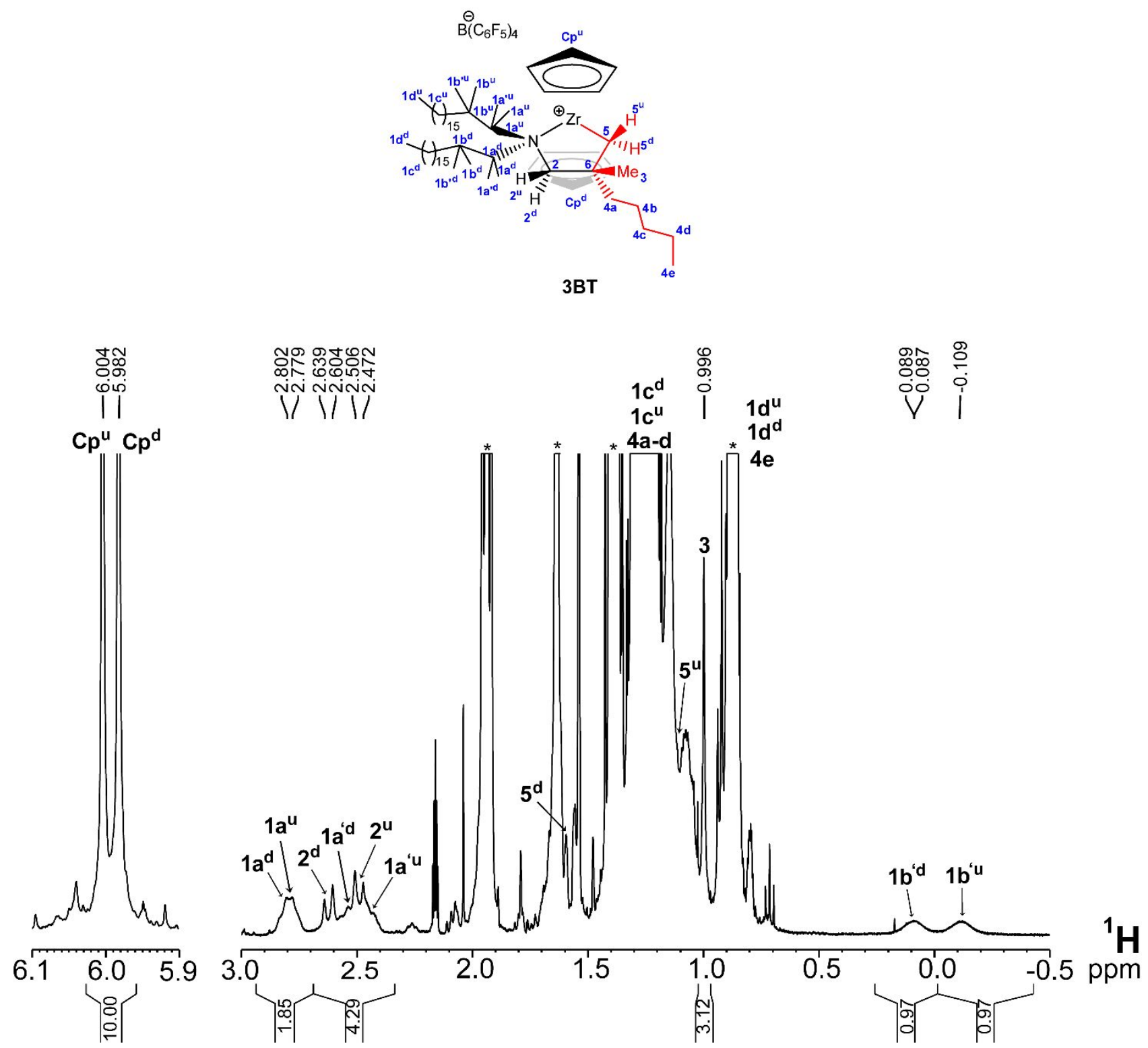

Figure S4. Sections of ${ }^{1} H$ NMR spectrum of 3 BT in benzene-d ${ }_{6}$ at 298K. Asterisks denote signals of unreacted 5. 
An example of the methodology for resonance assignment is showed below for 2BT. The assignment for all the other synthesized ion pairs $\mathbf{2 B N}$ and $\mathbf{3 B T}$ followed the same procedure.

The assignment of the resonances of 2BT started from the ${ }^{1} \mathrm{H}$ NMR signal at $\delta_{\mathrm{H}}=1.72 \mathrm{ppm}$, integrating for one proton, which exhibits a single-bond scalar correlation with the tertiary carbon at $\delta_{\mathrm{C}}=35.4 \mathrm{ppm}\left(\mathrm{see}{ }^{1} \mathrm{H},{ }^{13} \mathrm{C}\right.$ HSQC NMR spectrum in Figure S5) and two long-range scalar correlations with secondary carbon resonances at $\delta_{\mathrm{C}}=60.9 \mathrm{ppm}$ and $51.4 \mathrm{ppm}$ (Figure S5). Since the carbon chemical shift of the $\mathrm{CH}$ unit is much lower than those of adjacent $\mathrm{CH}_{2}$ moieties, the former can be unambiguously assigned to the carbon $\mathrm{C} 3$. The resonances of protons bonded to the carbon at $\delta_{\mathrm{C}}=60.9 \mathrm{ppm}$ were found at $\delta_{\mathrm{H}}=2.31 \mathrm{ppm}$ and $2.06 \mathrm{ppm}$. The latter show a strong NOE interaction with proton resonances at $\delta_{\mathrm{H}}=2.87,2.54,2.39$ and $2.14 \mathrm{ppm}$ that belong to the first methylene units of the alkyl chains on nitrogen $\left(\delta_{\mathrm{C}}=57.3 \mathrm{ppm}, 55.5 \mathrm{ppm}\right)$; consequently, the carbon resonances at $\delta_{\mathrm{C}}=60.9 \mathrm{ppm}$ and $\delta_{\mathrm{C}}=51.4 \mathrm{ppm}$ are assigned to $\mathrm{C} 2$ and $\mathrm{C} 4$, respectively. ${ }^{[3]}$ The chemical shifts of protons at $\mathrm{C} 4$ are found at $\delta_{\mathrm{H}}=1.42$ and $1.24 \mathrm{ppm}$ (Figure S5). Finally the two separate signals of Cp ligands are assigned on the basis of the strong dipolar $\mathrm{NOE}$ contact between $\mathrm{H} 3^{\mathrm{d}}$ and the $\mathrm{Cp}$ resonance at $\delta_{\mathrm{H}}=5.76 \mathrm{ppm}$ (which is arbitrarily labelled as $\mathrm{Cp}^{\mathrm{d}}$, Figure S6). All the remaining proton and carbon resonances are assigned by following scalar or dipolar connectivities, except for some $\mathrm{CH}_{2}$ moieties on the aliphatic chains, that give a complex broad signal in the ${ }^{1} \mathrm{H}$ spectral region between 1.5 and $1.0 \mathrm{ppm}$. Finally, the ${ }^{19} \mathrm{~F}$ spectrum of $\mathbf{2 B T}$ (Figure S7) exhibited a $\Delta \delta_{(\mathrm{pF}-\mathrm{mF})}=3.9 \mathrm{ppm}$, about $1.2 \mathrm{ppm}$ smaller than that of the starting $1 \mathrm{BT}\left(\Delta \delta_{(\mathrm{pF}-\mathrm{mF})}=\right.$ $5.1 \mathrm{ppm})$, in agreement with the shift of the anion from the inner to the outer coordination sphere. ${ }^{[2,3]}$

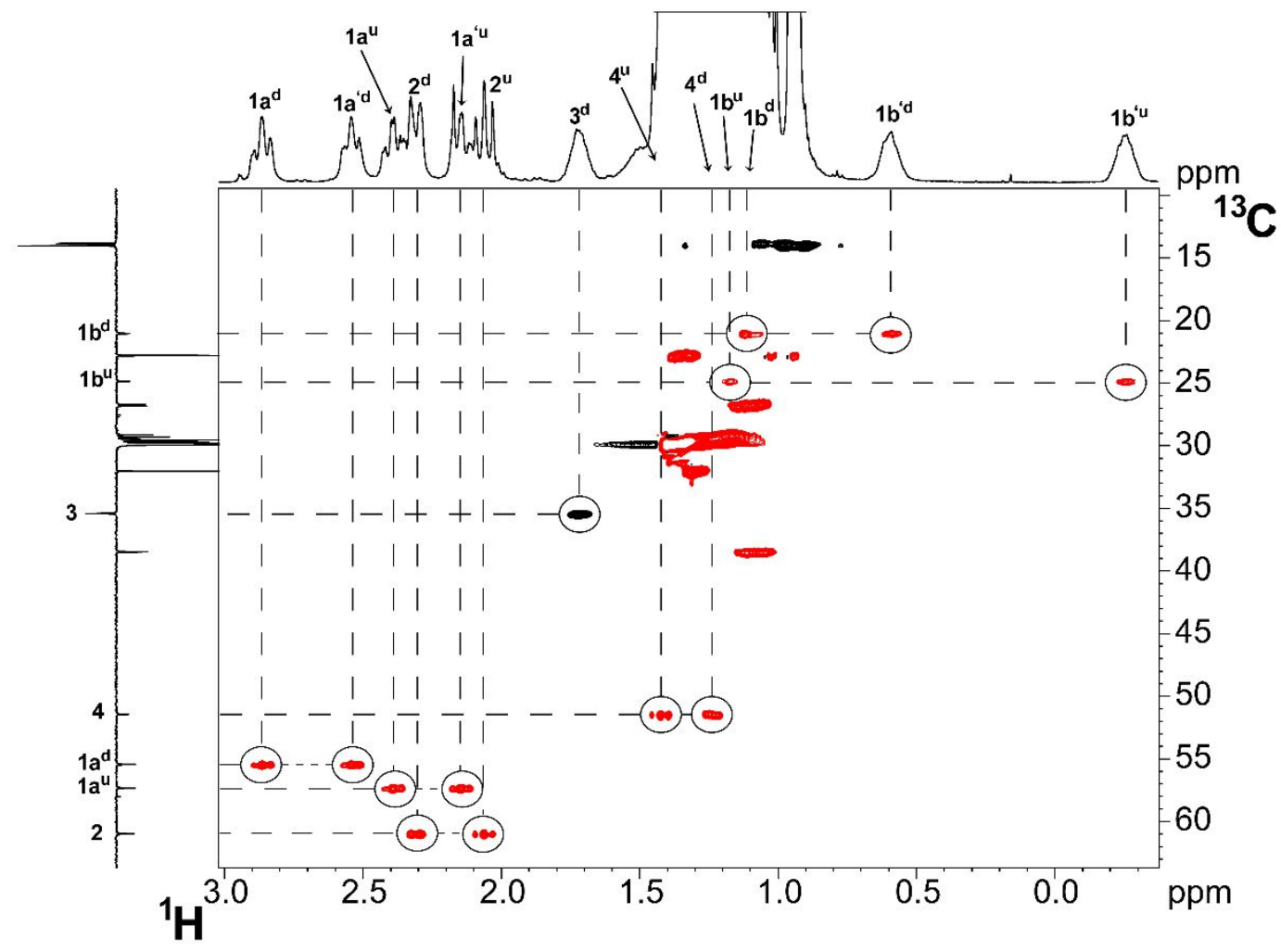

Figure S5. A Section of ${ }^{1} H,{ }^{13} \mathrm{C} H S Q C$ NMR spectrum of $2 \boldsymbol{B}$ T in $C_{6} D_{6}$ at $298 K$. 


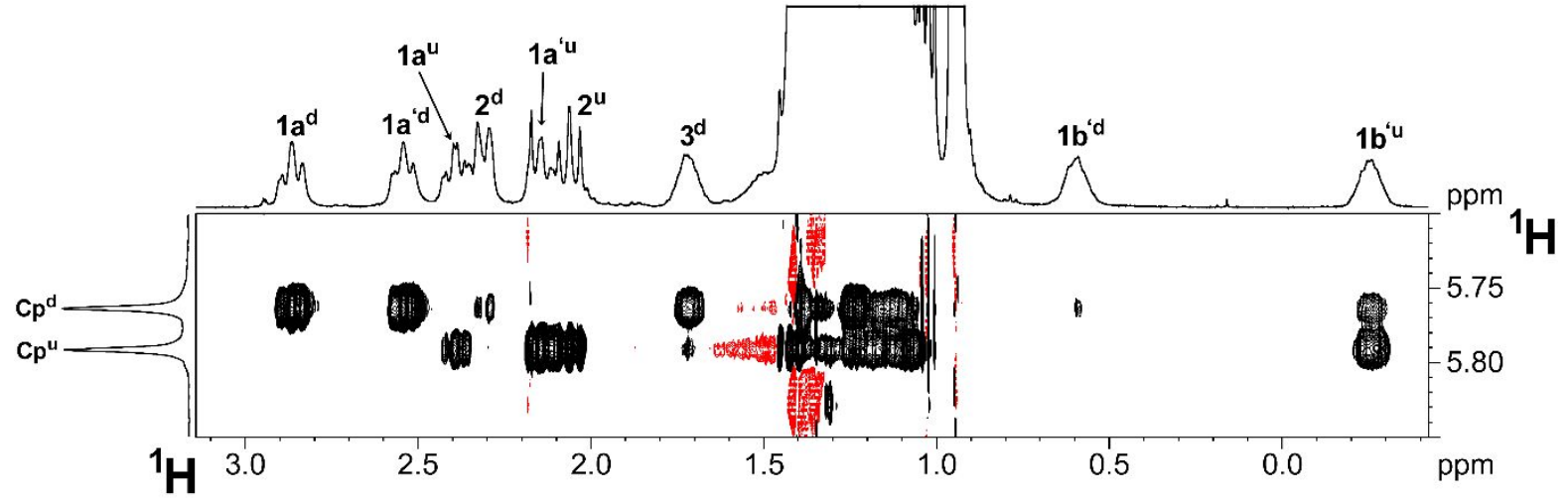

Figure S6. A Section of ${ }^{1} H,{ }^{1} H$ NOESY NMR spectrum of $\mathbf{2 B T}$ in $C_{6} D_{6}$ at $298 K$.

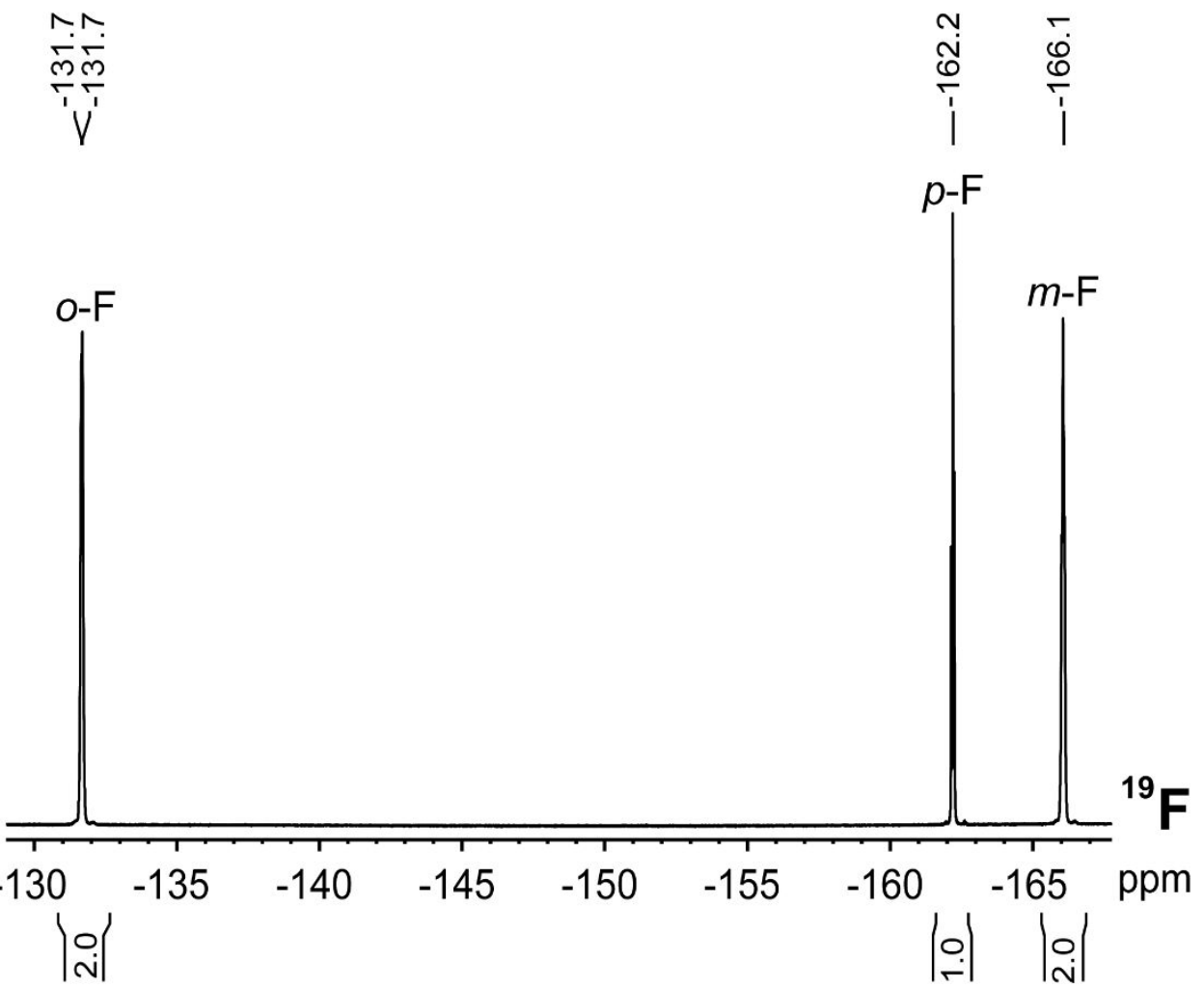

Figure S7. ${ }^{19} \mathrm{~F}$ NMR spectrum of $\mathbf{2 B T}$ in $C_{6} D_{6}$ at $298 \mathrm{~K}$. 


\section{Thermodynamic of Ion Pairs Self-Aggregation}

\section{- PGSE NMR Diffusion experiments}

${ }^{1} \mathrm{H}$ PGSE NMR measurements were performed on a Bruker Avance III HD 400 spectrometer equipped with a smart probe with a z gradient coil, by using the standard double-stimulated echo pulse sequence without spinning. ${ }^{[4]}$ The shape of the gradients was rectangular, their duration $(\delta)$ was $4 \mathrm{~ms}$, and their strength $(\mathrm{G})$ was varied during the experiments. All the spectra were acquired using $32 \mathrm{~K}$ points, 64 scans, spectral width of $5000 \mathrm{~Hz}$ and were processed with a line broadening of 1.0-3.0 Hz. The experiments were carried out with a total recycle delay of ca. $10 \mathrm{~s}$. The semilogarithmic plots of $\ln \left(\mathrm{I} / \mathrm{I}_{0}\right)$ versus $\mathrm{G}^{2}$ (a.u.) were fitted using a standard linear regression algorithm and a correlation factor better than 0.99 was always obtained. Self-diffusion coefficients $\left(D_{t}\right)$, proportional to the slope of linear fittings, were calculated using the diffusion coefficient of residual solvent resonance as internal reference standard. ${ }^{[5]}$ The latter was calibrated using an external sample of $\mathrm{HDO}$ in $\mathrm{D}_{2} \mathrm{O}$ (known diffusion coefficients in the range 274-318 K) under the same exact conditions as for the sample of interest. ${ }^{[6]} \mathrm{D}_{\mathrm{t}}$ data were treated as described in the literature in order to derive the hydrodynamic parameters (hydrodynamic radius, hydrodynamic volume and aggregation number). ${ }^{[7]}$ The measurements uncertainties were estimated by assuming approximately an error of $5 \%$ in the hydrodynamic radius and $15 \%$ hydrodynamic volume and aggregation number $\mathrm{N}$.

Diffusion experiments were carried out in methylcyclohexane- $\mathrm{d}_{14}$ and toluene- $\mathrm{d}_{8}$ at different temperature and different metallocenium ion pair concentration. Solutions were prepared inside the glove box by dissolving the species in $0.6 \mathrm{~mL}$. The metallocenium concentration was estimated from integration relative to an external standard; the uncertainty in $[\mathrm{Zr}]$ is assumed to be $\pm 10 \%$. Different concentrations were obtained by successive dilutions. Since the residual aliphatic resonances of methylcyclohexane- $\mathrm{d}_{14}$ are superimposed with those of the amine alkyl chains, a drop of benzene- $\mathrm{H}_{6}$ was added to the samples as a secondary internal standard. Linear fittings of $\ln \left(I / I_{0}\right)$ vs $G^{2}$ were performed for the Cp resonances of each compound and for the residual resonances of solvent or secondary internal standard.

Hydrodynamic volumes of ion pairs 1BN and 1BT in touene- $d_{8}\left(2088 \AA^{3}\right.$ and $2203 \AA^{3}$, respectively) and 1BN in methylcyclohexane- $\mathrm{d}_{14}\left(2620 \AA^{3}\right)$ were taken from experimental values in benzene- $\mathrm{d}_{6}$ and cyclohexane- $\mathrm{d}_{12}$ reported in the literature. ${ }^{[2]} \mathrm{V}_{\mathrm{H}}{ }^{0}$ of $\mathbf{1 B T}$ in methylcyclohexane- $\mathrm{d}_{14}\left(2620 \AA^{3}\right)$ was calculated considering that the ratio between $\mathrm{BN}$ and $\mathrm{BT}$ anions is equal to $1.236 .{ }^{[2]}$ Finally, $\mathrm{V}_{\mathrm{H}}{ }^{0}$ of $\mathbf{2} \mathbf{B N}$ in methylcyclohexane- $\mathrm{d}_{14}(2700$ $\AA^{3}$ ) was obtained from $\mathrm{V}_{\mathrm{H}}{ }^{0}$ of $\mathbf{1 B N}$ with the addition of $80 \AA^{3}$ associated to the ring expansion and olefin insertion. Diffusion NMR data are summarized in Tables S1-S3. Representative examples of semilogarithmic plots and the corresponding linear fittings are shown in Figures S8-S17. 
Table S1. Temperature ( $T, K)$, ion pair concentration ( $\left.[\mathrm{Zr}], 10^{-3} \mathrm{M}\right)$, diffusion coefficient $\left(\mathrm{D}_{t}, 10^{-10} \mathrm{~m}^{2} \mathrm{~s}^{-1}\right)$, hydrodynamic volume $\left(V_{H}, A^{3}\right)$ and aggregation number $(N)$ for $1 \mathrm{BN}, 1 \mathrm{BT}$ and $2 \mathrm{BN}$ in methylcyclohexane- $d_{14}$.

\begin{tabular}{|c|c|c|c|c|c|c|}
\hline Entry & Species & $\mathbf{T}$ & [Zr] & $\mathbf{D}_{\mathrm{t}}$ & $\mathbf{V}_{\mathbf{H}}$ & $\mathbf{N}$ \\
\hline 1 & \multirow{6}{*}{$1 B N$} & \multirow{6}{*}{248} & 14.1 & 1.81 & 20029 & 7.64 \\
\hline 2 & & & 10.1 & 1.96 & 15940 & 6.08 \\
\hline 3 & & & 7.0 & 2.24 & 10813 & 4.13 \\
\hline 4 & & & 4.0 & 2.70 & 6451 & 2.46 \\
\hline 5 & & & 1.6 & 3.04 & 4628 & 1.77 \\
\hline 6 & & & 0.5 & 3.13 & 4275 & 1.63 \\
\hline 7 & \multirow{6}{*}{$1 B N$} & \multirow{6}{*}{258} & 14.1 & 2.11 & 12976 & 4.95 \\
\hline 8 & & & 10.1 & 2.26 & 10578 & 4.04 \\
\hline 9 & & & 7.0 & 2.49 & 8099 & 3.09 \\
\hline 10 & & & 4.0 & 2.82 & 5680 & 2.17 \\
\hline 11 & & & 1.6 & 3.50 & 3145 & 1.20 \\
\hline 12 & & & 0.5 & 3.25 & 3845 & 1.47 \\
\hline 13 & \multirow{6}{*}{$1 \mathrm{BN}$} & \multirow{6}{*}{268} & 14.1 & 2.36 & 9347 & 3.57 \\
\hline 14 & & & 10.1 & 2.46 & 8385 & 3.20 \\
\hline 15 & & & 7.0 & 2.76 & 6073 & 2.32 \\
\hline 16 & & & 4.0 & 3.06 & 4528 & 1.73 \\
\hline 17 & & & 1.6 & 3.39 & 3439 & 1.31 \\
\hline 18 & & & 0.5 & 3.25 & 3809 & 1.45 \\
\hline 19 & \multirow{6}{*}{$1 B N$} & \multirow{6}{*}{278} & 14.1 & 2.52 & 7696 & 2.94 \\
\hline 20 & & & 10.1 & 2.67 & 6620 & 2.53 \\
\hline 21 & & & 7.0 & 2.95 & 5001 & 1.91 \\
\hline 22 & & & 4.0 & 3.25 & 3857 & 1.47 \\
\hline 23 & & & 1.6 & 3.60 & 2932 & 1.12 \\
\hline 24 & & & 0.5 & 3.53 & 3088 & 1.18 \\
\hline 25 & \multirow{11}{*}{ 1BT } & \multirow{11}{*}{258} & 29.5 & 0.75 & 271378 & 99.2 \\
\hline 26 & & & 19.4 & 0.90 & 156836 & 57.3 \\
\hline 27 & & & 18.1 & 0.89 & 164698 & 60.2 \\
\hline 28 & & & 12.5 & 1.01 & 113606 & 41.5 \\
\hline 29 & & & 5.96 & 1.18 & 70241 & 25.7 \\
\hline 30 & & & 4.45 & 1.32 & 50740 & 18.6 \\
\hline 31 & & & 4.08 & 1.41 & 41667 & 15.2 \\
\hline 32 & & & 1.06 & 1.76 & 21942 & 8.0 \\
\hline 33 & & & 0.46 & 2.17 & 11962 & 4.4 \\
\hline 34 & & & 0.124 & 2.25 & 10718 & 3.9 \\
\hline 35 & & & 0.08 & 3.17 & 4124 & 1.5 \\
\hline 36 & \multirow{5}{*}{$2 \mathrm{BN}$} & \multirow{5}{*}{258} & 4.56 & 1.19 & 68876 & 25.5 \\
\hline 37 & & & 2.86 & 2.17 & 53575 & 19.8 \\
\hline 38 & & & 0.76 & 2.11 & 23196 & 8.6 \\
\hline 39 & & & 0.25 & 1.72 & 12923 & 4.8 \\
\hline 40 & & & 0.15 & 1.30 & 11887 & 4.4 \\
\hline
\end{tabular}



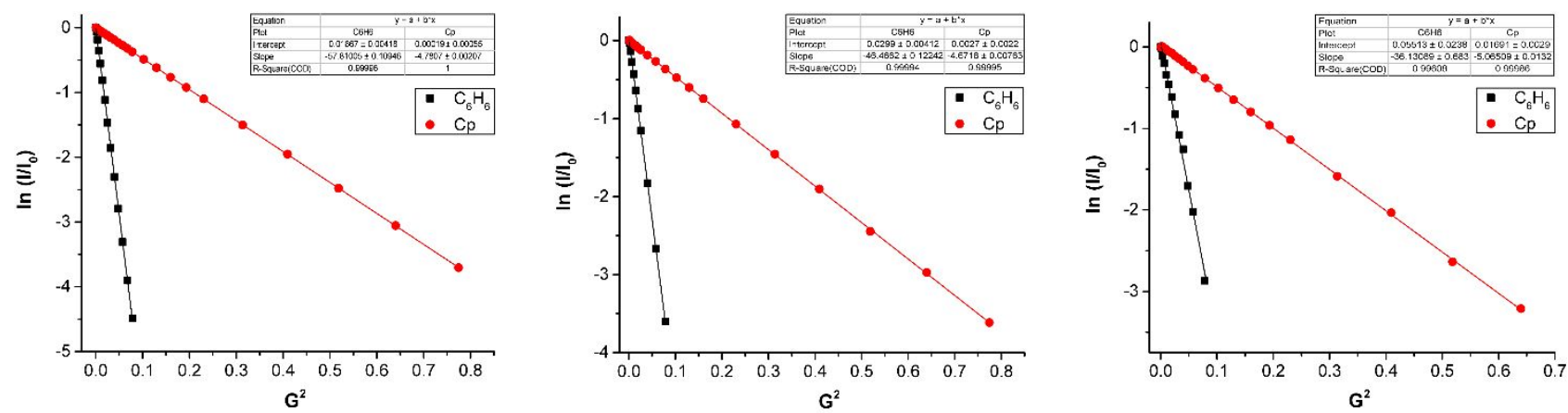

Figure S8. Semilogarithmic plots of $\ln \left(I / I_{0}\right)$ vs $G^{2}$ (a.u.) of $\mathbf{1 B N}$ (red circles) and $C_{6} H_{6}$ (black squares) at $248 \mathrm{~K}$ for [1BN] $14.1 \mathrm{mM}$ (left, Table S1 entry 1), $7.0 \mathrm{mM}$ (middle, Table S1 entry 3) and $0.5 \mathrm{mM}$ (right, Table S1 entry 6).
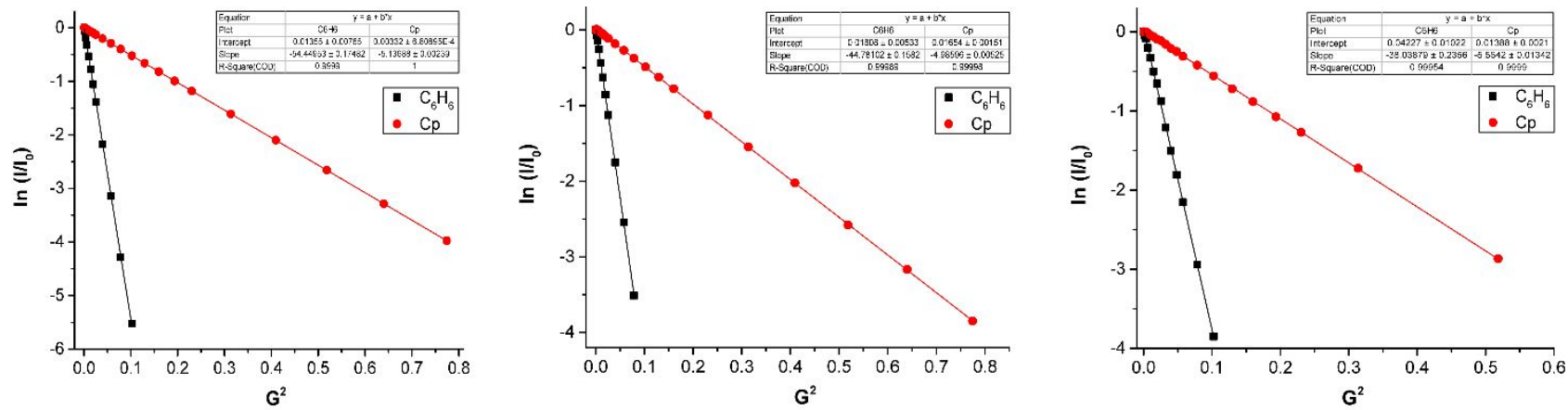

Figure S9. Semilogarithmic plots of $\ln \left(I / I_{0}\right)$ vs $G^{2}$ (a.u.) of $\mathbf{1 B N}$ (red circles) and $C_{6} H_{6}$ (black squares) at $258 \mathrm{~K}$ for [1BN] $14.1 \mathrm{mM}$ (left, Table S1 entry 7), $7.0 \mathrm{mM}$ (middle, Table S1 entry 9) and $0.5 \mathrm{mM}$ (right, Table S1 entry 12).
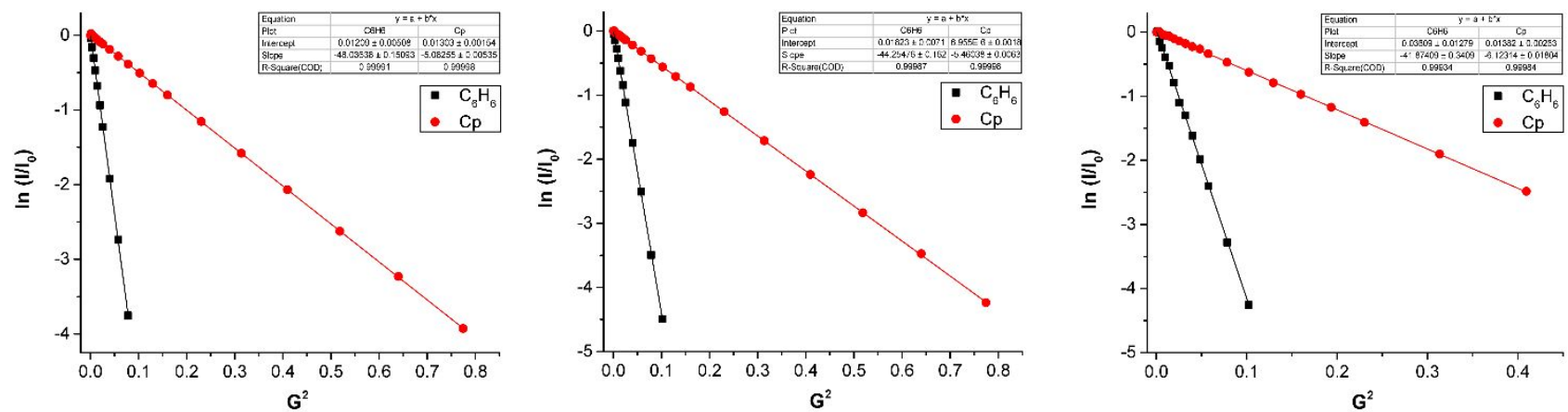

Figure S10. Semilogarithmic plots of $\ln \left(I / I_{0}\right)$ vs $G^{2}$ (a.u.) of $\mathbf{1 B N}$ (red circles) and $C_{6} H_{6}$ (black squares) at $268 K$ for [1BN] $14.1 \mathrm{mM}$ (left, Table S1 entry 13), $7.0 \mathrm{mM}$ (middle, Table S1 entry 15) and $0.5 \mathrm{mM}$ (right, Table S1 entry 18).
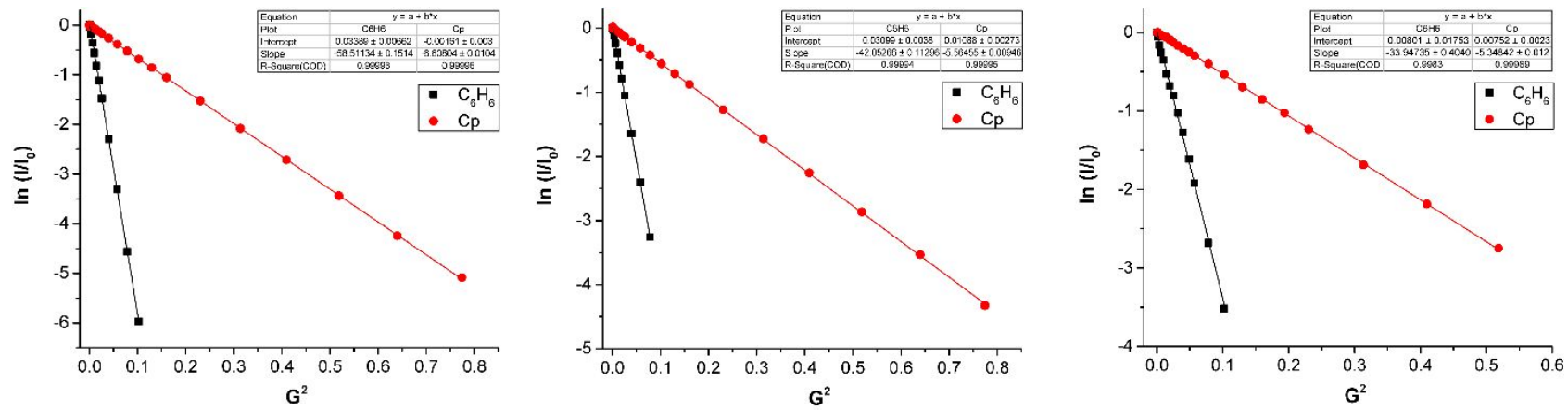

Figure S11. Semilogarithmic plots of $\ln \left(I / I_{0}\right)$ vs $G^{2}$ (a.u.) of $\mathbf{1 B N}$ (red circles) and $C_{6} H_{6}$ (black squares) at $278 K$ for [1BN] = $14.1 \mathrm{mM}$ (left, Table S1 entry 19), $7.0 \mathrm{mM}$ (middle, Table S1 entry 21) and $0.5 \mathrm{mM}$ (right, Table S1 entry 24). 

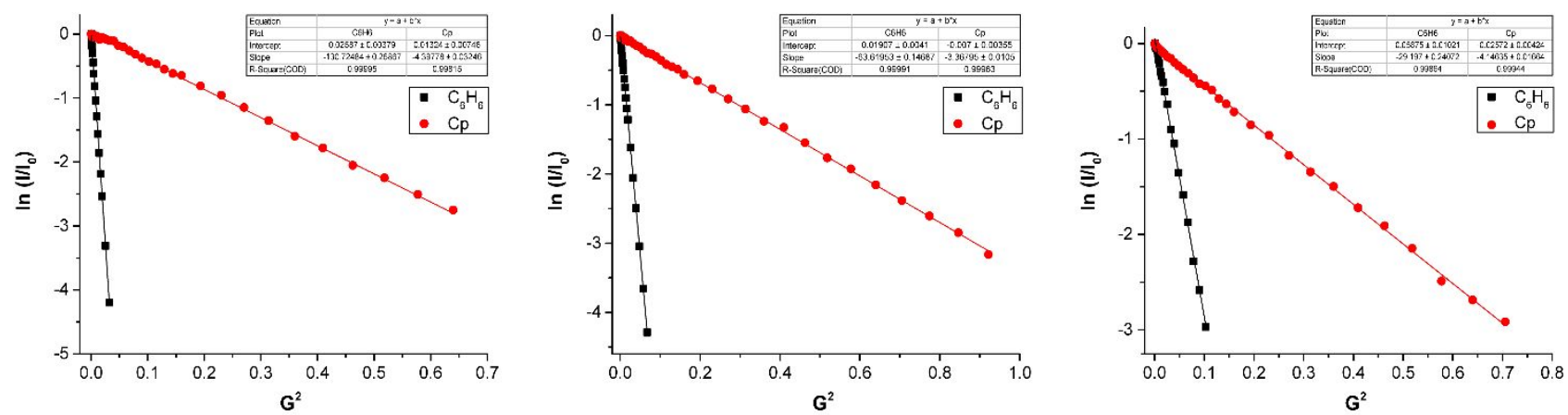

Figure S12. Semilogarithmic plots of $\ln \left(I / I_{0}\right)$ vs $G^{2}$ (a.u.) of $\mathbf{1 B T}$ (red circles) and $C_{6} H_{6}$ (black squares) at $258 K$ for $[\mathbf{1 B T}]$ = $29.5 \mathrm{mM}$ (left, Table S1 entry 25), $5.96 \mathrm{mM}$ (middle, Table S1 entry 29) and 0.08 mM (right, Table S1 entry 35).
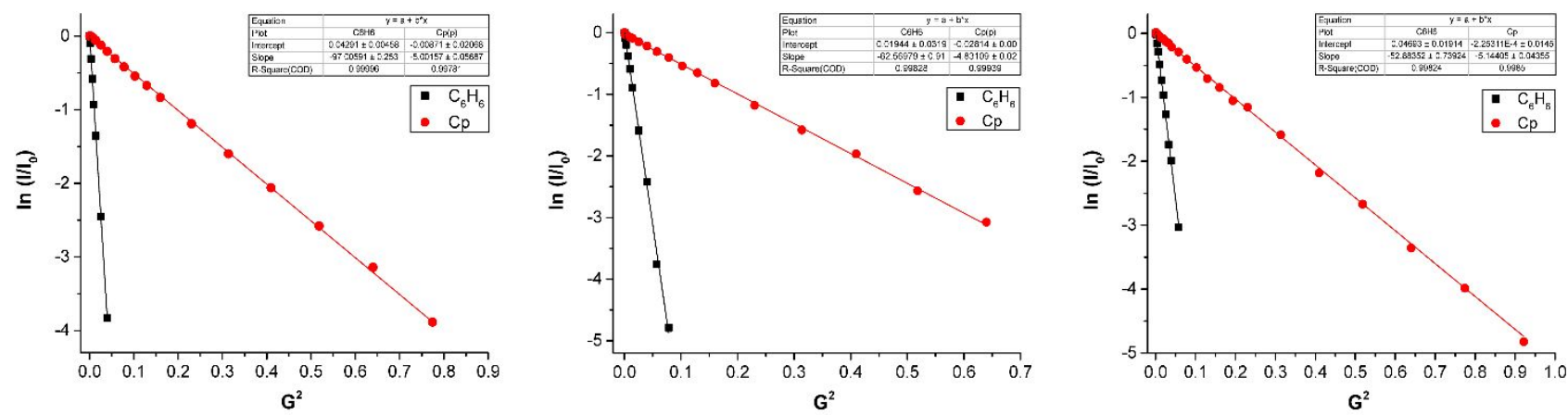

Figure S13. Semilogarithmic plots of $\ln \left(I / I_{0}\right)$ vs $G^{2}$ (a.u.) of $\mathbf{2 B N}$ (red circles) and $C_{6} H_{6}$ (black squares) at $258 K$ for [1BT] $=4.56 \mathrm{mM}$ (left, Table S1 entry 36), $0.76 \mathrm{mM}$ (middle, Table S1 entry 38) and $0.15 \mathrm{mM}$ (right, Table S1 entry 40). 
Table S2. Temperature $(T, K)$, ion pair concentration $\left([\mathrm{Zr}], 10^{-3} \mathrm{M}\right)$, diffusion coefficient $\left(\mathrm{D}_{t}, 10^{-10} \mathrm{~m}^{2} \mathrm{~s}^{-1}\right)$, hydrodynamic volume $\left(V_{H}, A^{3}\right)$ and aggregation number $(N)$ for $\mathbf{1 B N}$ and $\mathbf{1 B T}$ in toluene- $d_{8}$.

\begin{tabular}{|c|c|c|c|c|c|c|}
\hline Entry & Species & $\mathbf{T}$ & [Zr] & $D_{t}$ & $\mathbf{V}_{\mathbf{H}}$ & $\mathbf{N}$ \\
\hline 1 & \multirow{8}{*}{$1 B N$} & \multirow{8}{*}{223} & 20.0 & 2.93 & 8415 & 4.0 \\
\hline 2 & & & 16.6 & 3.13 & 6967 & 3.3 \\
\hline 3 & & & 11.7 & 3.31 & 5961 & 2.9 \\
\hline 4 & & & 7.73 & 3.58 & 4819 & 2.3 \\
\hline 5 & & & 4.6 & 3.56 & 4860 & 2.3 \\
\hline 6 & & & 1.64 & 3.93 & 3704 & 1.8 \\
\hline 7 & & & 0.87 & 3.87 & 3869 & 1.9 \\
\hline 8 & & & 0.09 & 4.03 & 3472 & 1.7 \\
\hline 9 & \multirow{7}{*}{$1 B N$} & \multirow{7}{*}{258} & 73.6 & 2.86 & 8998 & 4.3 \\
\hline 10 & & & 19.2 & 3.66 & 4509 & 2.2 \\
\hline 10 & & & 15 & 3.76 & 4199 & 2.0 \\
\hline 11 & & & 10.4 & 3.91 & 3756 & 1.8 \\
\hline 12 & & & 3.5 & 4.18 & 3145 & 1.5 \\
\hline 13 & & & 1.5 & 4.31 & 2887 & 1.4 \\
\hline 14 & & & 0.33 & 4.38 & 2771 & 1.3 \\
\hline 15 & \multirow{8}{*}{$1 \mathrm{BT}$} & \multirow{8}{*}{223} & 5.65 & 2.16 & 20370 & 9.2 \\
\hline 16 & & & 4.52 & 2.23 & 18400 & 8.4 \\
\hline 17 & & & 2.91 & 2.54 & 12750 & 5.8 \\
\hline 18 & & & 2.80 & 2.55 & 12593 & 5.7 \\
\hline 19 & & & 2.50 & 2.64 & 11415 & 5.2 \\
\hline 20 & & & 1.18 & 3.10 & 7198 & 3.3 \\
\hline 21 & & & 0.77 & 3.02 & 7743 & 3.5 \\
\hline 22 & & & 0.28 & 3.42 & 5452 & 2.5 \\
\hline
\end{tabular}
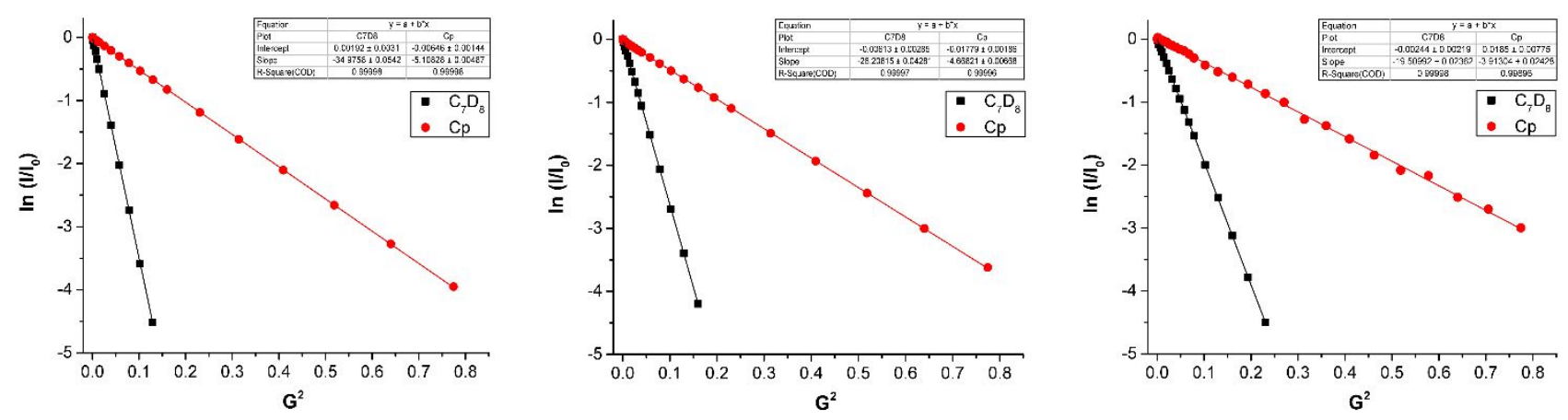

Figure S14. Semilogarithmic plots of $\ln \left(I / I_{0}\right)$ vs $G^{2}$ (a.u.) of $\mathbf{1 B N}$ (red circles) and $C_{7} D_{8}$ (black squares) at $223 \mathrm{~K}$ for [1BN] = $20.0 \mathrm{mM}$ (left, Table S2 entry 1), $7.73 \mathrm{mM}$ (middle, Table S2 entry 4) and $0.09 \mathrm{mM}$ (right, Table S2 entry 8). 

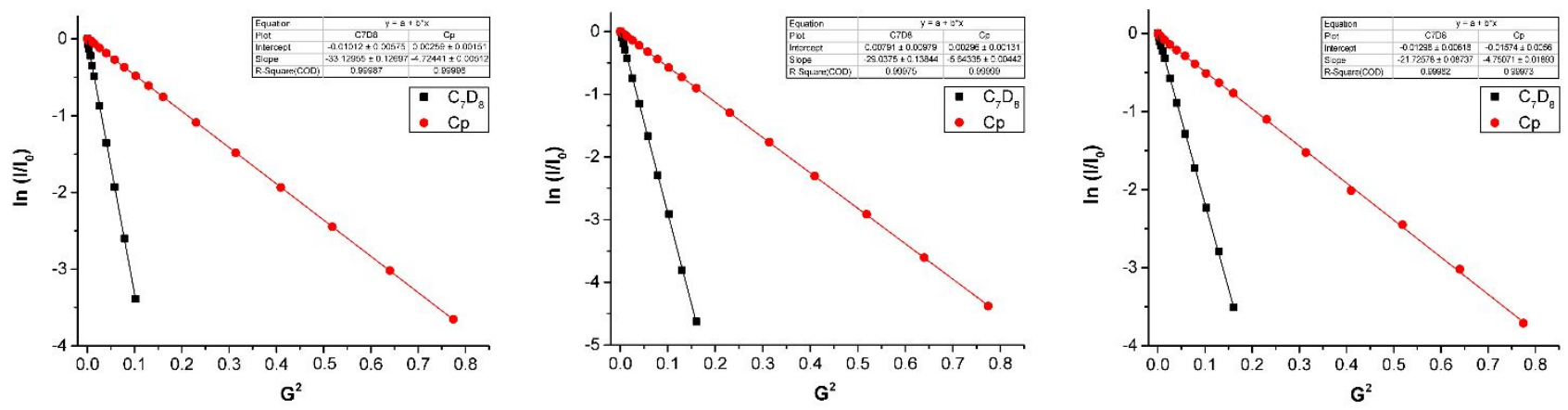

Figure S15. Semilogarithmic plots of $\ln \left(I / I_{0}\right)$ vs $G^{2}$ (a.u.) of $\mathbf{1 B N}$ (red circles) and $C_{7} D_{8}$ (black squares) at $258 K$ for [1BN] = $73.6 \mathrm{mM}$ (left, Table S2 entry 9), $10.4 \mathrm{mM}$ (middle, Table S2 entry 11) and $0.33 \mathrm{mM}$ (right, Table S2 entry 14).
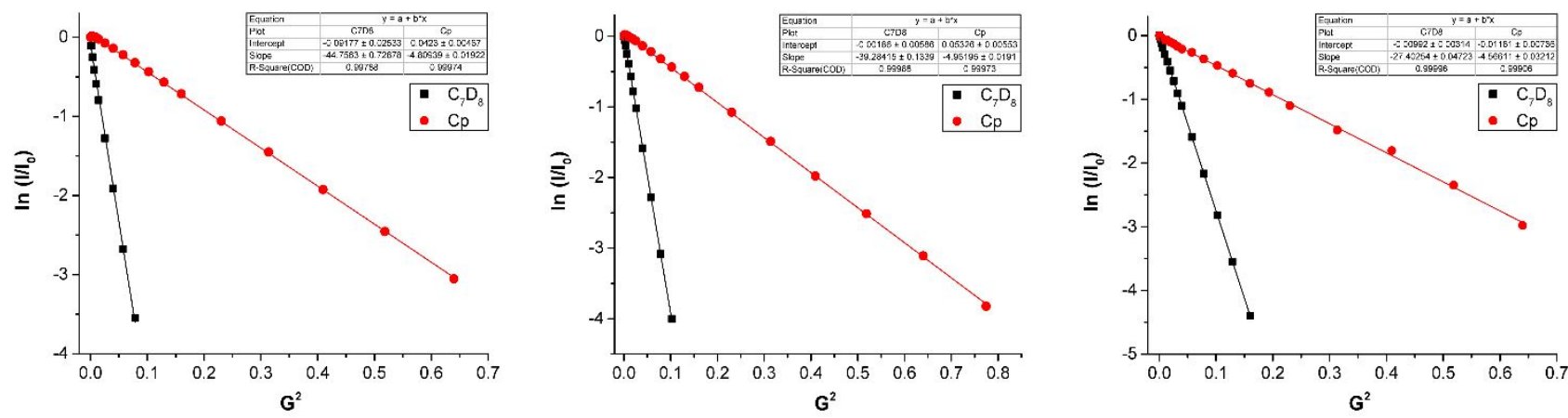

Figure S16. Semilogarithmic plots of $\ln \left(I / I_{0}\right)$ vs $G^{2}$ (a.u.) of $\mathbf{1 B T}$ (red circles) and $C_{7} D_{8}$ (black squares) at $223 \mathrm{~K}$ for [1BT] = $5.65 \mathrm{mM}$ (left, Table S2 entry 15), $2.80 \mathrm{mM}$ (middle, Table S2 entry 18) and 0.28 mM (right, Table S2 entry 22).

Table S3. Diffusion coefficient $\left(D_{t}, 10^{-10} \mathrm{~m}^{2} \mathrm{~s}^{-1}\right)$, hydrodynamic volume $\left(V_{H}, A^{3}\right)$ and aggregation number $(N)$ of $1 \mathbf{B N}$ as a function of total ion pair concentration $\left([\mathrm{Zr}]_{\text {tot }}=[1 \mathrm{BN}]+[2 \mathrm{BN}], 10^{-3} \mathrm{M}\right)$ in methylcyclohexane- $d_{14}$ at $258 \mathrm{~K}$.

\begin{tabular}{ccccccc} 
Entry & {$[\mathbf{Z r}]_{\text {tot }}$} & {$[\mathbf{1 B N}]$} & {$[\mathbf{2 B N}]$} & $\mathbf{D}_{\mathbf{t}}$ & $\mathbf{V}_{\mathbf{H}}$ & $\mathbf{N}$ \\
\hline 1 & 0.62 & 0.62 & - & 3.51 & 3129 & 1.2 \\
2 & 1.15 & 0.62 & 0.55 & 3.27 & 3786 & 1.4 \\
3 & 2.52 & 0.62 & 1.9 & 2.84 & 5519 & 2.1 \\
4 & 5.19 & 0.79 & 4.4 & 2.27 & 10450 & 4.0 \\
\hline
\end{tabular}
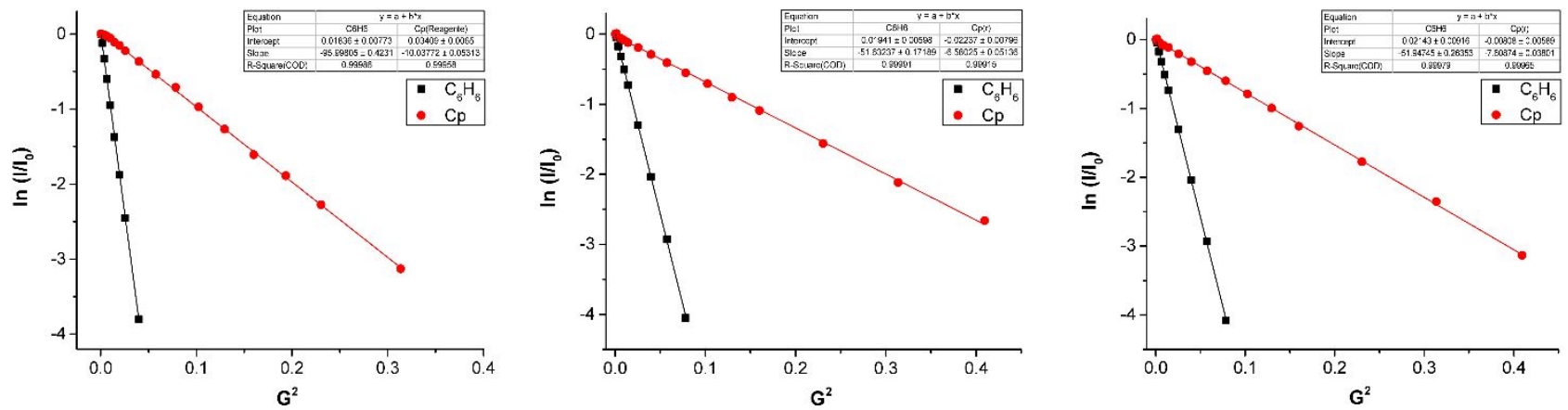

Figure S17. Semilogarithmic plots of $\ln \left(\mathrm{I} / \mathrm{I}_{0}\right)$ vs $G^{2}$ (a.u.) of $\mathbf{1 B N}$ (red circles) and $C_{6} H_{6}$ (black squares) at $258 \mathrm{Kfor}[\mathrm{Zr}]_{\text {tot }}$ $=5.19 \mathrm{mM}$ (left, Table S3 entry 4), $2.52 \mathrm{mM}$ (middle, Table S3 entry 3) and $1.15 \mathrm{mM}$ (right, Table S3 entry 2). 


\section{- Thermodynamic parameters of self-aggregation}

Experimental trends of $\mathrm{N}$ vs [Zr] (Table S1, S2 and S3) were analysed using three different models for indefinite self-aggregation data: EK (equal K), IK (incremental K) and AK (attenuated K). ${ }^{[9]}$ The dependence of the weight fraction of the monomer $(\alpha)$ and the aggregation number $(\mathrm{N})$ as a function of analytical concentration $(\mathrm{C})$ is given by the equations shown in Table S4. ${ }^{[2,8]}$ The IK model gives always the best fit, whereas the AK model is often unable to reach convergence (Figure S18). ${ }^{[2]}$ Examples of $\mathrm{N}$ vs $[\mathrm{Zr}]$ curve fitting are shown in Figure S19-S21. Values of limiting self-aggregation constant are summarized in Table S5. The Van't Hoff plot of $K_{I}$ in the temperature range of $248 \mathrm{~K}-278 \mathrm{~K}$ is shown in Figure S21 for $\mathbf{1 B N}$ in methylcyclohexane- $\mathrm{d}_{14}$.

Table S4. Equations used to calculate the weight fraction of the monomer $(\alpha)$ and the aggregation number $(N)$ at a given analytical concentration with IK, EK and AK models.

\begin{tabular}{ccc} 
Model & $\boldsymbol{\alpha}$ & $\mathbf{N}$ \\
\hline IK & $\alpha\left(\mathrm{K}_{\mathrm{I}} \mathrm{C}+1\right)-1=0$ & $\left(\mathrm{~K}_{\mathrm{I}} \mathrm{C}\right) /\left[\ln \left(\mathrm{K}_{\mathrm{I}} \mathrm{C}+1\right)\right]$ \\
EK & $\alpha^{2}\left(\mathrm{~K}_{\mathrm{e}} \mathrm{C}\right)^{2}-\alpha\left(2 \mathrm{~K}_{\mathrm{e}} \mathrm{C}+1\right)+1=0$ & $1 /\left(1-\alpha \mathrm{K}_{\mathrm{e}} \mathrm{C}\right)$ \\
$\mathrm{AK}$ & $\alpha-\mathrm{e}^{-\alpha \mathrm{KaC}}=0$ & $\left(\mathrm{~K}_{\mathrm{a}} \mathrm{C}\right) /[(1 / \alpha)-1]$ \\
\hline
\end{tabular}

Table S5. Species, Temperature (K), Solvent and calculated equilibrium constant with IK model $\left(K_{I}, M^{-1}\right)$ for $1 \mathbf{B N}, 1 B \boldsymbol{B}$ and $2 B \boldsymbol{B}$. Uncertainties in $K_{I}$ values are quoted at $95 \%$ confidence level as computed by the fitting algorithm.

\begin{tabular}{|c|c|c|c|c|}
\hline Entry & Species & $\mathbf{T}$ & Solvent & $\mathbf{K}_{\mathbf{I}}$ \\
\hline 1 & 1BN & 248 & Methylcyclohexane-d $\mathrm{d}_{14}$ & $1648 \pm 116$ \\
\hline 2 & $1 \mathrm{BN}$ & 258 & Methylcyclohexane-d $\mathrm{d}_{14}$ & $901 \pm 59$ \\
\hline 3 & $1 \mathrm{BN}$ & 268 & Methylcyclohexane-d $\mathrm{d}_{14}$ & $557 \pm 31$ \\
\hline 4 & $1 \mathrm{BN}$ & 278 & Methylcyclohexane-d $\mathrm{d}_{14}$ & $374 \pm 18$ \\
\hline 5 & 1BT & 258 & Methylcyclohexane-d $\mathrm{d}_{14}$ & $19800 \pm 2123$ \\
\hline 6 & $2 B N$ & 258 & Methylcyclohexane- $\mathrm{d}_{14}$ & $28846 \pm 5770$ \\
\hline 7 & $1 B N$ & 223 & Toluene- $\mathrm{d}_{8}$ & $470 \pm 118$ \\
\hline 8 & $1 B N$ & 258 & Toluene- $\mathrm{d}_{8}$ & $149 \pm 45$ \\
\hline 9 & 1BT & 223 & Toluene- $\mathrm{d}_{8}$ & $5936 \pm 502$ \\
\hline
\end{tabular}




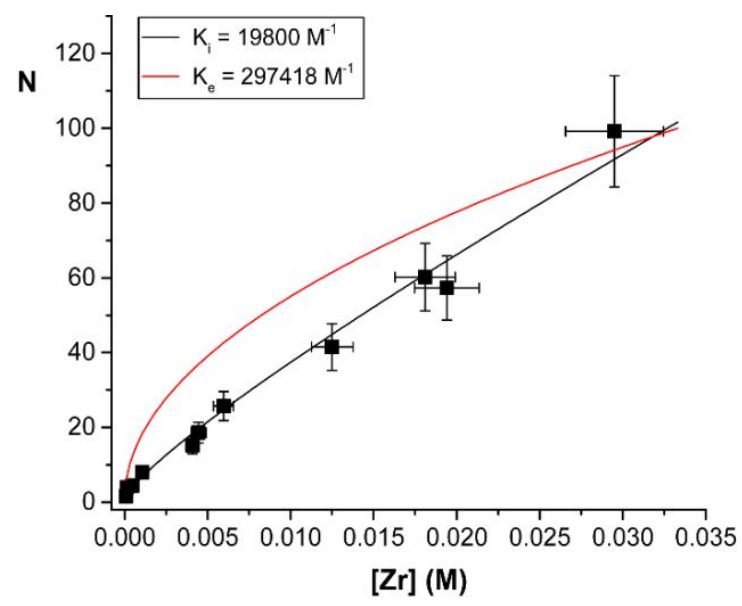

Figure S18. Comparison between the best fittings resulting from the application of IK (black line) or EK (red line) indefinite aggregation models on the experimental trend of $N$ as function of concentration (M) for $1 B \mathrm{BT}$ at $258 \mathrm{~K}$ in methylcyclohexane- $d_{14}$.

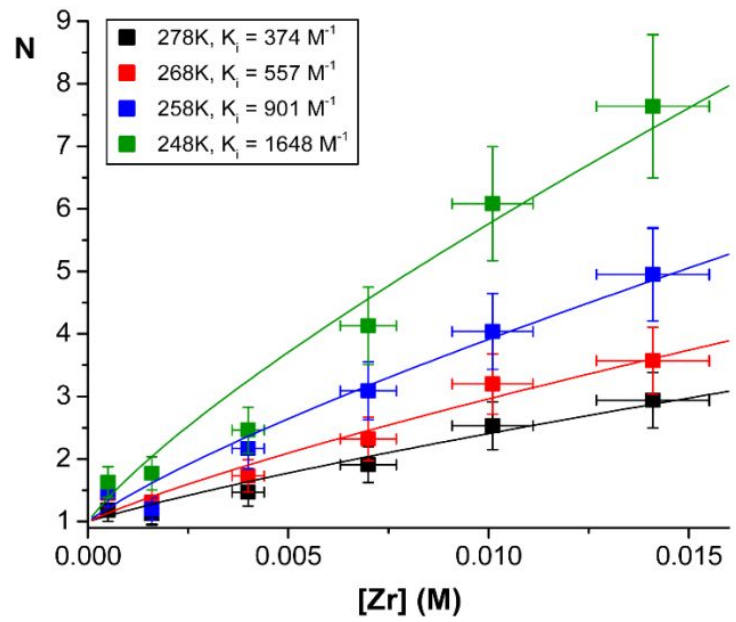

Figure S19. Self-aggregation trends of $1 \mathrm{BN}$ as function of concentration ([Zr], M) and temperature (T, K) at $278 \mathrm{~K}$ (black squares), $268 \mathrm{~K}$ (red squares), $258 \mathrm{~K}$ (blue squares) and $248 \mathrm{~K}$ (green squares) in methylcyclohexane- $d_{14}$. Curves represent the best fit of indefinite aggregation model IK.

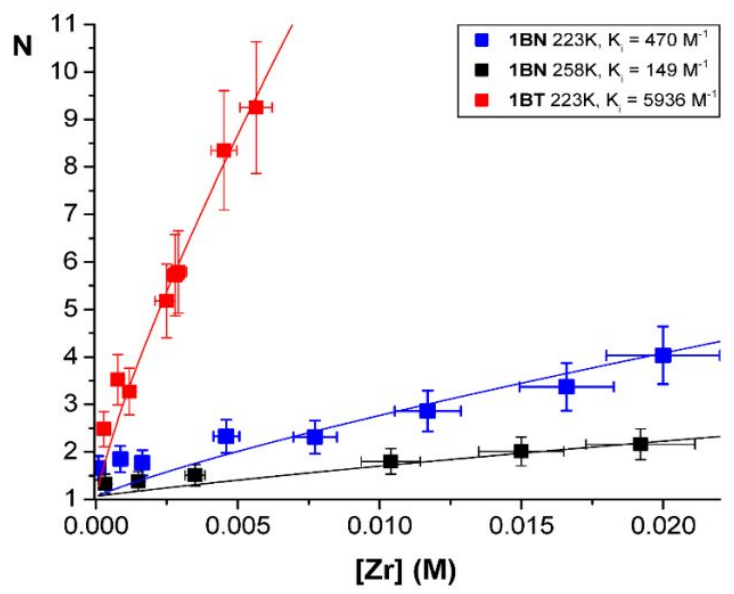

Figure S20. Self-aggregation trends of $1 B N$ and $1 B T$ as function of concentration ([Zr], $M)$ and temperature (T, K) at $223 \mathrm{~K}$ (blue squares for $1 \mathrm{BN}$ and red squares for 1BT) and $258 \mathrm{~K}$ (black squares for 1BN) in toluene- $d_{8}$. Curves represent the best fit of the indefinite aggregation model IK. 


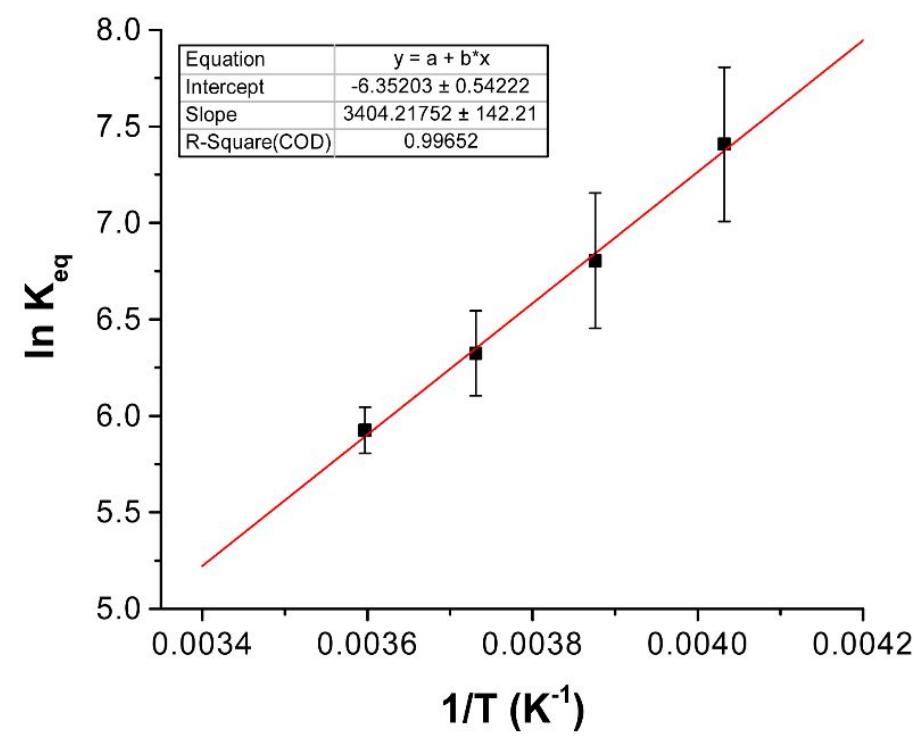

Figure S21. Van't Hoff plot for the self-aggregation equilibrium process of 1 BN in methylcyclohexane-d $d_{14}(248 K-278 K)$. 


\section{Kinetic of olefin insertion}

For each kinetic run at high concentration (typically above $[\mathrm{Zr}]>0.5-1 \mathrm{mM}$ ), solutions of $\mathbf{1 B N}$ or $\mathbf{1 B T}$ in methylcyclohexane- $\mathrm{d}_{14}$ or toluene- $\mathrm{d}_{8}(0.6 \mathrm{~mL})$ were loaded into a NMR tube equipped with a screw cap and a PTFE septum inside the glovebox. A solution of the olefin (4 or $\mathbf{5}$ ) was prepared inside the glovebox dissolving the suitable amount of olefin in $0.2 \mathrm{~mL}$ of the corresponding solvent (methylcyclohexane- $\mathrm{d}_{14}$ or toluene- $\mathrm{d}_{8}$ ) and loaded in a gas-tight syringe equipped with a long needle. Outside the glovebox, the NMR tube was kept at $-20^{\circ} \mathrm{C}$ (for kinetic run at $258 \mathrm{~K}$ ) or $-60^{\circ} \mathrm{C}$ (for kinetic run at $223 \mathrm{~K}$ ) using an alcohol or acetone/liquid nitrogen bath. The olefin solution was quickly injected into the NMR tube through the septum, taking care to add the solution from the bottom of the NMR tube to speed up mixing. The tube was immediately transferred into the pre-cooled NMR probe set at the desired temperature of the kinetic experiment and acquisition of the first ${ }^{1} \mathrm{H}$ NMR spectrum was started 120 seconds after injection to allow temperature equilibration. The progress of the reaction was monitored by acquiring a series of single-scan ${ }^{1} \mathrm{H}$ NMR spectra at regular intervals of 44 seconds. The kinetic profiles were obtained by simultaneously monitoring the integral values of $\mathrm{Cp}$ and olefinic resonances of reagents and the two $\mathrm{Cp}$ resonances associate with the products. For kinetic runs at [Zr] well below $0.5 \mathrm{mM}$, the procedure was modified slightly, to further reduce the small contamination of the solution, arising from adventitious moisture and/or oxygen from drilling of the PTFE septum in open air. In this case, the needle of the gas-tight syringe, loaded with the olefin solution, was inserted into the NMR tube, containing the zirconium solution, through the PTFE septum inside the glove box, taking care not to mix the solutions. Outside the glove box, the solution contained in NMR tube with the attached gas-tight syringe was cooled as above, and once the desired temperature was attained, the olefin solution was injected. For slow kinetics and very low $[\mathrm{Zr}]$, the interval between ${ }^{1} \mathrm{H}$ NMR spectra was optimized and, when necessary 8 scans were averaged. Representative examples of the reactant consumption and product formation as a function of time are shown in Figures S22 and S23.
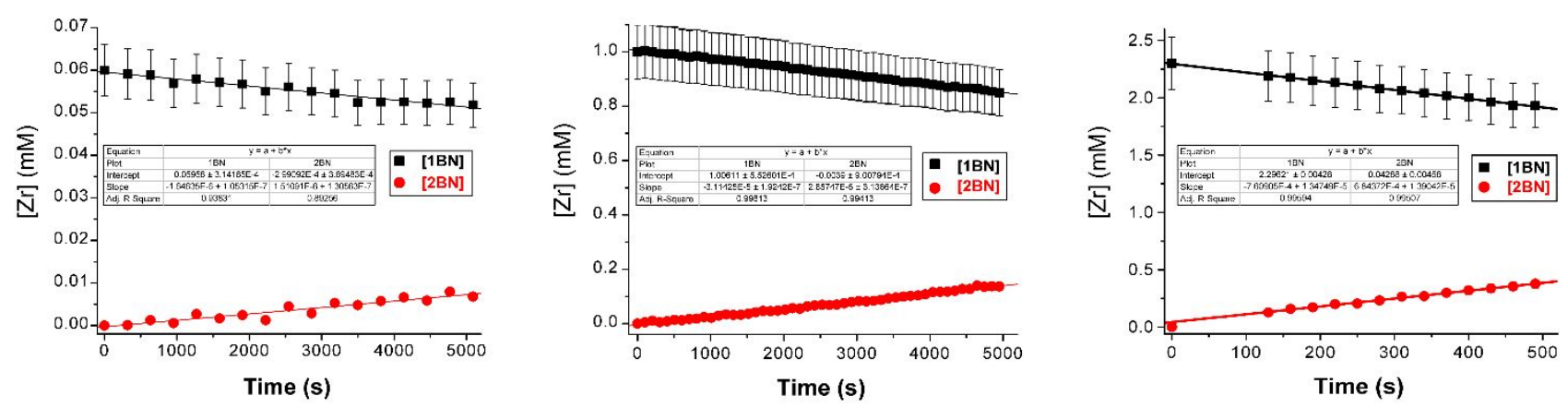

Figure S22. Concentrations vs time profiles for reactant consumption and product formation in methylcyclohexane- $d_{14}$ at $258 \mathrm{~K}$ for the reaction of $1 \mathbf{B N}$ with 4 . Left: $[\mathbf{1 B N}]=0.06 \mathrm{mM},[4]=4.5 \mathrm{mM}$ (Table 2, entry 1 in the main text); Middle: $[\mathbf{B N N}]=1.0 \mathrm{mM},[4]=2.0 \mathrm{mM}$ (Table 2, entry 6 in the main text); Right: $[\mathbf{1 B N}]=2.3 \mathrm{mM},[4]=10.3 \mathrm{mM}$ (Table 2 entry 9 in the main text). 

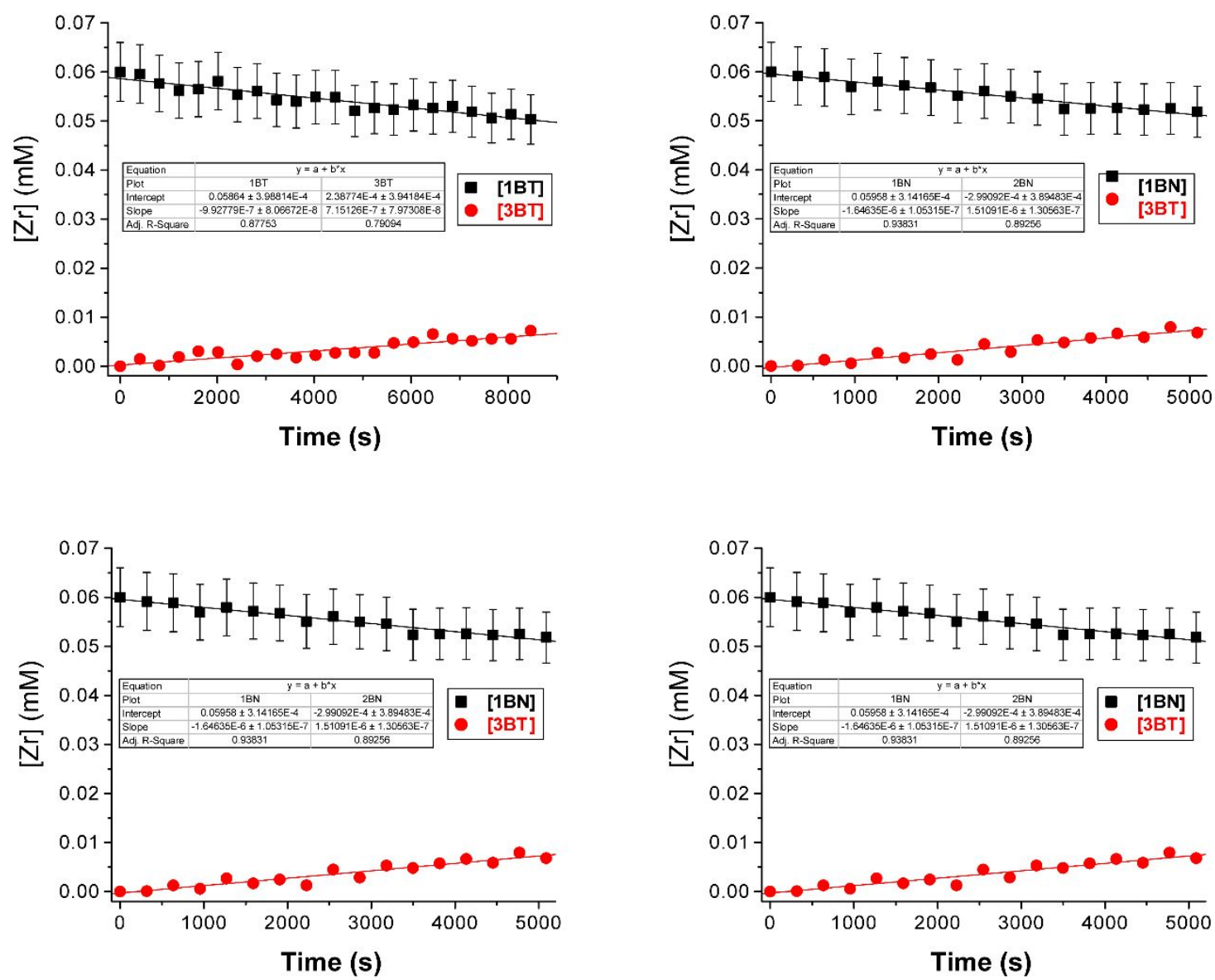

Figure S23. Concentrations vs time profiles for reactant consumption and product formation in methylcyclohexane- $d_{14}$ at $258 \mathrm{~K}$ for reaction of 1BT with 5. Top Left: [1BT] = $0.06 \mathrm{mM},[5]=0.8 \mathrm{mM}$ (Table 2, entry 35 in the main text); Top Right: [1BT] = 0.08 $\mathrm{mM},[5]=2.7 \mathrm{mM}$ (Table 2, entry 38 in the main text); Bottom Left: [1BT] = $0.8 \mathrm{mM},[5]=18.7 \mathrm{mM}$ (Table 2, entry 44 in the main text); Bottom Right: [1BT] = $2.05 \mathrm{mM},[5]=24.5 \mathrm{mM}$ (Table 2, entry 46 in the main text). 


\section{References}

[1] Samuel, E.; Raush, M.D. $\pi$-Cyclopentadienil and $\pi$-Indenyl Compounds of Titanium, Zirconium and Hafnium Containing $\sigma$-Bonded Organic Substituents. J. Am. Chem. Soc. 1973, 95, 6263-6267.

[2] Rocchigiani, L.; Bellachioma, G.; Ciancaleoni, G.; Macchioni, A.; Zuccaccia, D.; Zuccaccia, C. Synthesis, Characterization, Interionic Structure, and Self-Aggregation Tendency of Zirconaaziridinium Salts Bearing Long Alkyl Chains. Organometallics 2011, 30, 100-114.

[3] Rocchigiani, L.; Ciancaleoni, G.; Zuccaccia, C.; Macchioni, A. Low-Temperature Kinetic NMR Studies on the Insertion of a Single Olefin Molecule into a $\mathrm{Zr}-\mathrm{C}$ Bond: Assessing the Counterion-Solvent Interplay. Angew. Chem. Int. Ed. 2011, 50, 11752-11755.

[4] Valentini, M.; Rüegger, H.; Pregosin, P. S. Applications of Pulsed-Gradient Spin-Echo (PGSE) Diffusion Measurements in Organometallic Chemistry. Helv. Chim. Acta 2001, 84, 2833-2853 and references therein.

[5] Zuccaccia, D.; Macchioni, A. An Accurate Methodology to Identify the Level of Aggregation in Solution by PGSE NMR Measurements: The Case of Half-Sandwich Diamino Ruthenium(II) Salts Organometallics 2005, 24, 3476-3486.

[6] Mills, R. J. Self-Diffusion in Normal and Heavy Water in the Range 1-45 . Phys. Chem. 1973, 77, 685688.

[7] Macchioni, A.; Ciancaleoni, G.; Zuccaccia, C.; Zuccaccia, D. Determining accurate molecular sizes in solution through NMR diffusion spectroscopy. Chem. Soc. Rev. 2008, 37, 479-489.

[8] Rocchigiani, L.; Bellachioma, G.; Ciancaleoni, G.; Crocchianti, S.; Laganà, A.; Zuccaccia, C.; Zuccaccia, D.; Macchioni, A. Anion-Dependent Tendency of Di-Long-Chain Quaternary Ammonium Salts to Form Ion Quadruples and Higher Aggregates in Benzene ChemPhysChem 2010, 11, 3243-3254

[9] Martin, R. B. Comparisons of Indefinite Self-Association Models. Chem. Rev. 1996, 96, 3043-3064. 